\title{
Study of the ecosystem of the lagoon of Venice, with emphasis on anthropogenic impact
}

\author{
Yu. I. Sorokin ${ }^{1}$, P. Yu. Sorokin ${ }^{1}$, O. Giovanardi ${ }^{2, *}$, L. Dalla Venezia ${ }^{3}$ \\ ${ }^{1}$ Southern Dept. of Oceanology, Gelendzhik-7, Krasnodar district, 353470 Russia \\ ${ }^{2}$ Istituto Centrale per la Ricerca Scientifica e Tecnologica Applicata al Mare (ICRAM), viale della Stazione 5, \\ I-30015 Chioggia, Italy \\ ${ }^{3}$ Istituto di Biologia del Mare, CNR, Riva Sette Martiri 1364, I-30122 Venice, Italy
}

\begin{abstract}
The parameters of the structure and functioning of the ecosystem in the lagoon of Venice (Italy) were estimated in September-October 1993 at 36 stations. Phytoplankton was dominated by its nano- and pico-fractions, which comprised 60 to $99 \%$ of the total phytoplankton biomass. Phytoplankton wet biomass varied between 100 and $600 \mathrm{mg} \mathrm{m}^{-3}$ and its primary production between 30 and $90 \mathrm{mg}$ $\mathrm{C} \mathrm{m}^{-2} \mathrm{~d}^{-1}$ The numerical abundance of bacterioplankton ( 3 to $6 \times 10^{6}$ cells $\mathrm{ml}^{-1)}$ and its wet biomass $\left(0.3\right.$ to $\left.1 \mathrm{~g} \mathrm{~m}^{-3}\right)$ was 2 to 3 times greater than in adjacent waters of the Adriatic. Bacterial production was 20 to $40 \mathrm{mg} \mathrm{C} \mathrm{m}^{-3} \mathrm{~d}^{-1}$. Microzooplankton was dominated by ciliates with biomasses of 30 to $700 \mathrm{mg} \mathrm{m}^{-3}$, while the density of rotifers and nauplii was low. The composition of mesozooplankton resembled that of the Adriatic complex only near the port entrances connecting the lagoon to the sea, while in polluted areas it was drastically depleted. Its average wet biomass was 80 to $300 \mathrm{mg} \mathrm{m}^{-3}$, attanining 700 to 1100 $\mathrm{mg} \mathrm{m}^{-3}$ near the port entrances. The total plankton biomass was 0.8 to $2 \mathrm{~g} \mathrm{~m}^{-3}$, and was dominated by microplankton. The stock of labile organic matter in the lagoon was 2 to 3 times greater than in the waters of the adjacent Adriatic, with a turnover time which vaned between 10 and $20 \mathrm{~d}$. The stock of labile sulfides in the upper layer of the bottom sediments in the central basin of the lagoon was 1.5 to $2 \mathrm{~g} \mathrm{~S} \mathrm{dm}^{-3}$ of wet silt. Data were generalized using the approach of energy balances and energy flows. The latter were used to evaluate the present state of the ecosystem of the lagoon of Venice, its changes due to anthropogenic impact, and its capability for self-purification.
\end{abstract}

KEY WORDS: Lagoon of Venice - Energy flows · Biomass · Primary production

\section{INTRODUCTION}

The lagoon of Venice (Italy) is situated in the NW part of the Adriatic, north of the Po delta. It is a large (about $10 \times 50 \mathrm{~km}$ ) shallow marine basin with salinity of 32 to $36 \%$ (Fig 1). It stretches along the Adriatic coast, and is separated from the sea by 3 long islands with wide port entrances between them, through which water exchange between lagoon and sea is driven by wind and tidal currents. Although the depths over old river beds or channels in the lagoon are 3 to $5 \mathrm{~m}$, on average depths range between 1 and $3 \mathrm{~m}$.

The southern basin is still relatively ecologically safe, but the central basin is subjected to a high level

\footnotetext{
- Addressee for correspondence.

E-mail: icramve@ipdunidx.unipd.it
}

of civil and industrial pollution, receiving wastewaters from the cities of Venice, Marghera and Mestre. Industrial wastewater and oil come from the Marghera refineries, the port areas of Venice and Marghera, and from numerous cargo ships and tankers. The northern basin is characterized by moderate anthropogenic impact. The most important negative environmental factor here is the high turbidity of the water

In spite of significant efforts by local and international researchers (UNESCO 1988, Cattani \& Corni 1992, Dalla Venezia 1996), the general picture of the structure and functioning of the Venice lagoonal ecosystem still remains unclear. The current situation is worrisome, in view of its apparent degradation, with signs of anoxia in bottom layers in summer, degradation of zooplankton, and build-up of sulfides 


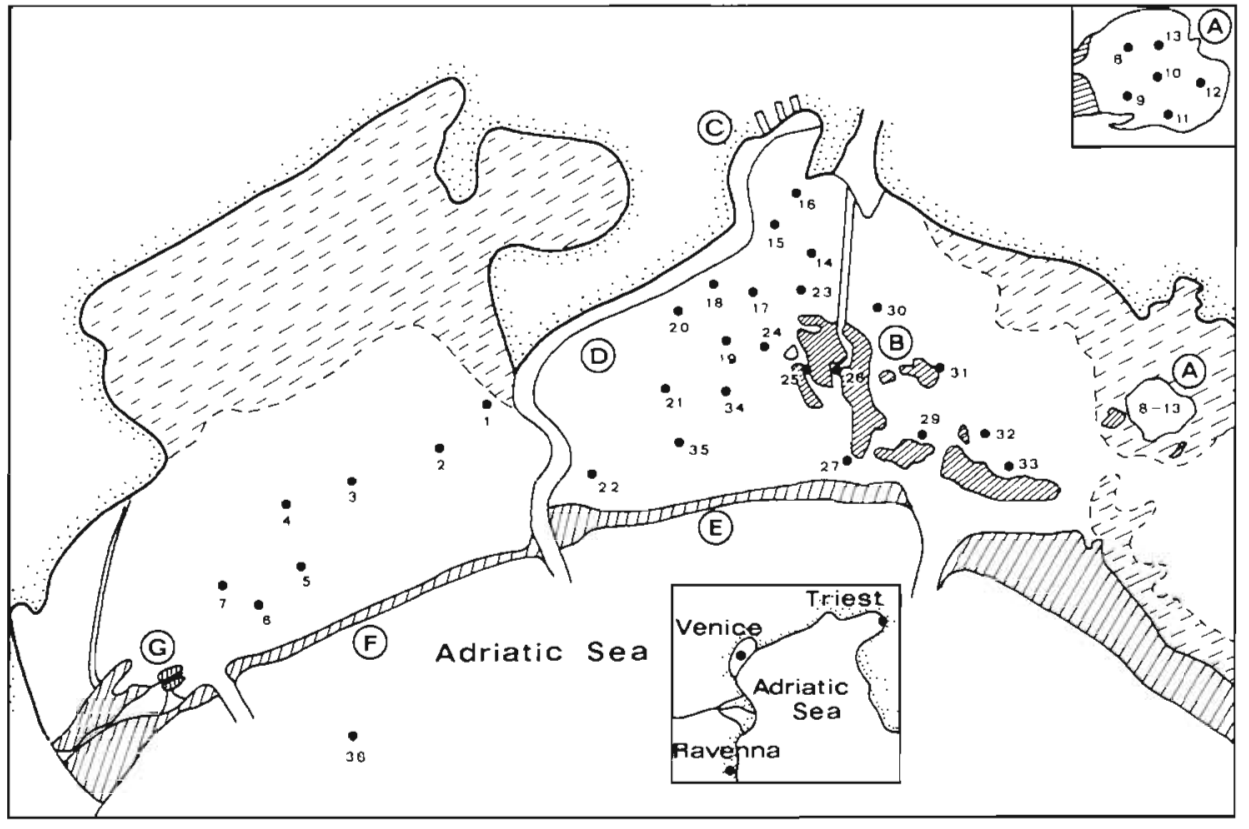

Fig. 1. Locations of stations in lagoon of Venice (Ttaly). A: Sublagoon of Palude della Rosa ('northern area'); B: City of Venice ('central area'); C: Marghera industrial area ('central area'); D: Malamocco channel ('central area'); E: Island of Lido ('central area'); F: Island of Pellestrina ('southern ared'); G: City of Chioggia ('southern area') in the upper layers of bottom sediments, accompanied by a shift in composition of bottom flora to domination by monospecific populations of the saprobic alga Ulva and a clear decrease in zoobenthic density and variability (Sorokin 1975a, 1982a, Carbognin \& Gatto 1981, Cescon \& Grancini 1981, Perin \& Gabelli 1983, Zucchetta 1983). Separate sets of data on several hydrophysical, hydrochemical and hydrobiological parameters in the lagoon of Venice by various scientific bodies show many gaps, and still do not give a definite holistic evaluation of its real ecological status. The deficiency of information on important and currently prevailing components of lagoonal plankton such as bacterioplankton and animal microheterotrophs does not facilitate realistic evaluations of available suspended food for short-neck clams Tapes philippinarum, the farming of which has recently been promoted on the bottom of the lagoon.

Available data on the density and distribution of other traditionally estimated plankton fractions are also invalid or insufficient, not only because of their patchiness in space and time, but also because their collection and quantification use outdated, invalid or insufficient methodologies like the Lugol sedimentation method for phytoplankton quantification or daytime net tows for collection of mesozooplankton. The former underestimates the fractions of small phytoplankton by 50 to $90 \%$; the latter underestimates planktonic crustaceans, cladocerans and copepods by 2 to 3 times (Bernhard et al. 1967, Pavelieva \& Sorokin 1972, Sukhanova \& Ratkova 1977). The latter method also underestimates demersal zooplankton, as its real biomass in lagoonal environments often exceeds that of the holoplankton daytime net mesozooplankton biomass by 1 order of magnitude or more (Sorokin 1993).

Other gaps in ecological knowledge about the lagoon of Venice regard a rather unstable oxygen regime in some areas and the build-up of labile sulfides in sediments (Sorokin 1975a, 1982a). We had the opportunity to investigate the abovementioned problems in September-October 1993.

\section{MATERIAL AND METHODS}

Research was based at the Chioggia Laboratory of ICRAM. One of the sampling boats was provided by ISDGM-CNR in Venice and visited 35 stations in 4 main parts of the basin. southern ('ChioggiaMalamocco' area, Stns 1 to 7 ), central ('VeniceMurano-Lido' area, Stns 22 to 35, together with the 'Marghera-Malamocco-Alberoni' area, Stns 14 to 21), and northern ('Palude della Rosa' sub-lagoon, Stns 8 to 13). The fourth part, Stn 36, was located in the Adriatic off the island of Pellestrina, at a depth of $15 \mathrm{~m}$.

Field work was accomplished during 5 field trips to the main areas of the lagoon of Venice. At each station samples were collected in plastic water bottles from a depth of about $1 \mathrm{~m}$. The southern basin and the station off the island of Pellestrina were sampled 
on September 24 ; the northern and central basins were sampled respectively on September 29 and on October 9-11, 1993. At some stations deeper than $4 \mathrm{~m}$, samples were also taken from the near-bottom layer, but no significant stratification in microplankton distribution was recorded, except at Stn $15 \quad 16 \mathrm{~m}$ deep). At most other stations, depths were between 1 and $3 \mathrm{~m}$. The tables therefore present data for the upper 0.5 to $1 \mathrm{~m}$ layer.

The total plankton biomass was estimated by counting its main groups: phytoplankton, bacterioplankton, nanoheterotrophs (basically zooflagellates), ciliates, rotifers, nauplii and mesozooplankton. Epifluorescence microscopy was used for quantification and sizing of bacteria, picoplanktonic algae $<3 \mu \mathrm{m}$, nanoplanktonic algae, nanoheterotrophs and nanociliates in the range 3 to $30 \mu \mathrm{m}$ (Caron 1983, Sherr \& Sherr 1983). Nano-and picoplanktonic algae and protozoans were counted on $0.4 \mathrm{um}$ black Nuclepore filters stained with fluorochrome primuline. Bacterioplankton was counted on $0.2 \mu \mathrm{m}$ pore size filters stained with acridine orange (Hobbie et al. 1977). Of the picophytoplankton, 2 fractions were counted separately: eukaryotic phytoflagellates and picocyanobacteria. Microalgae $>30 \mu \mathrm{m}$, the larger fraction of ciliates and rotifers, were counted in untreated water samples in glass chambers of $15 \mathrm{ml}$ capacity, according to Sorokin (1980). Mesozooplankton was counted in samples collected by passing $50 \mathrm{l}$ of water through a $40 \mu \mathrm{m}$ mesh plankton net. Biomasses were calculated in accordance with the average biovolumes of the measured organisms (Tchislenko 1968). All biomass values refer to wet weight.

The primary production of phytoplankton was estimated using the ${ }^{14} \mathrm{C}$ method, as modified by Sorokin (1987). Samples were incubated in situ in the sea for 2 to $3 \mathrm{~h}$. Photosynthetic production measured per hour was then calculated per day with the aid of coefficients, which were estimated experimentally by measuring the diurnal course of photosynthesis in the upper water layer of the lagoon in late September (Fig. 2). Primary production per $\mathrm{m}^{2}$ was calculated using the curve of the dependence of the photosynthesis rate on light attenuation in the water column, taking into account the Secchi disk transparency measured at each station (Fig. 3). That curve was established experimentally by exposing series of bottles containing identical water samples at various depths (Sorokin 1960). Production of bacterioplankton was estimated using the ${ }^{14} \mathrm{C}$ dark uptake method, as modified by Sorokin (1990). Total plankton respiration (decomposition rate, TM) was estimated by measuring oxygen consumption in bottles incubated in the dark at the in situ temperature for $24 \mathrm{~h}$. Bacterial respiration in carbon units (MB) was calculated from the values of

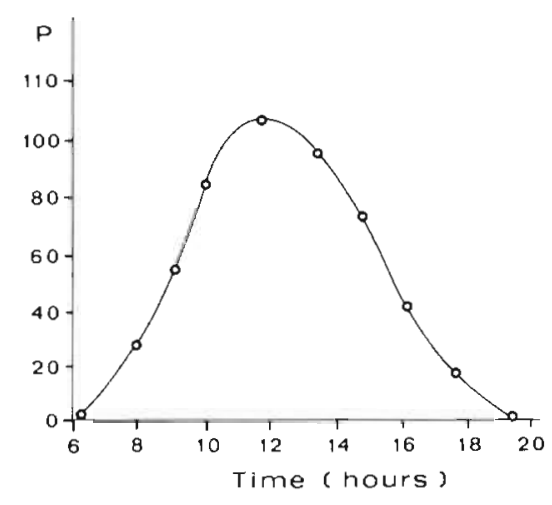

Fig. 2. Time course of photosynthesis rate ( $P$, relative values) during the day

bacterial production (BP): $\mathrm{MB}=\mathrm{BP}\left(1-K_{2}\right) / K_{2}$, where $K_{2}$ (efficiency coefficient of the use of assimilated food for growth) was 0.32 .

The content of labile organic matter (LOM) in water was estimated by the BOD-30 method (Sorokin \& Mamaeva 1980). Its stock in water was calculated as: $\mathrm{LOM}=(\mathrm{BOD}-30) \times 0.55 \mathrm{mg} \mathrm{Cl} \mathrm{Cl}^{-1}$, with BOD-30 being expressed in oxygen units ( $\mathrm{mg} \mathrm{O}_{2} \mathrm{I}^{-1}$ ). Suspended organic matter was collected on glass fiber filters. Contents of organic matter were estimated by wet chromic combustion at $130^{\circ} \mathrm{C}$ for $1 \mathrm{~h}$ with $\mathrm{AgSO}_{4}$ as catalyst. Acid-soluble sulfides in bottom sediments were estimated in samples preserved with a solution of $\mathrm{ZnSO}_{4}+\mathrm{Na}_{2} \mathrm{CO}_{3}$ and kept refrigerated for not more than 1 to 2 wk. Acid-soluble (labile) sulfide was extracted from samples by distillation from acidified samples in special apparatus (Sorokin 1975a, 1982a) The resulting $\mathrm{H}_{2} \mathrm{~S}$ was trapped by a mixture of $\mathrm{ZnSO}_{4}$ $+\mathrm{Cd}$-acetate $+\mathrm{KOH}$ and then estimated jodometrically.

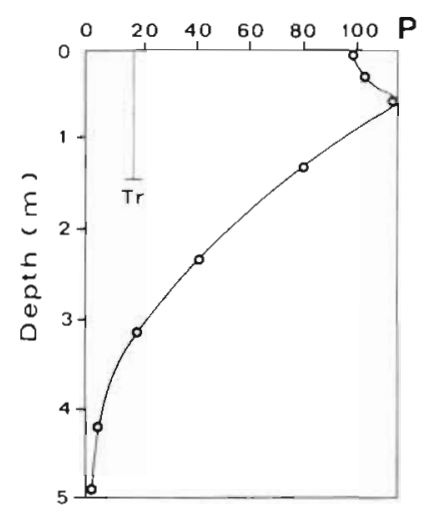

Fig. 3. Dependence of photosynthesis rate in water column $\left(P\right.$, relative values) on light attenuation with depth $\left(K_{l}\right.$ : curve); Tr: Secchi disk water transparency 


\section{RESULTS}

The results of estimates (Tables $1-4$ ) refer to sets of selected stations representing the ranges of values within each area investigated. Some basic parameters are also shown in Table 5 as averages of values obtained at all stations in a given area.

\section{Density and composition of plankton}

The results of phytoplankton quantification are given in Tables 1 \& 5. They demonstrate that, during our research, phytoplankton was dominated by the nano- and pico-fractions, as regards both the composition of its total biomass and its numerical abundance. The nano-fraction of phytoplankton was mostly represented by 3 to $10 \mu \mathrm{m}$ chrysomonadic phytoflagellates. Their numbers varied between 2 and $20 \times 10^{6}$ cells $1^{-1}$ and comprised 60 to $90 \%$ of the total phytoplankton biomass. The pico-fraction was represented by 2 to $3 \mu \mathrm{m}$ eukaryotic phytoflagellates. At some stations $(1-3,14,15,23)$ a significant part of this fraction (20 to $80 \%$ of the biomass) was composed of picocyanobacteria, although at most stations their quota was negligible. The number of picoalgae varied between 15 and $185 \times 10^{6} \mathrm{I}^{-1}$, and their biomass at several stations reached 100 to $150 \mathrm{mg} \mathrm{m}^{-3}$. The highest density

Table 1. Size composition, numerical abundance $\left(N\right.$, cells $\left.\mathrm{l}^{-1}\right)$, and wet biomass $\left(B, \mathrm{mg} \mathrm{m}^{-3}\right)$ of phytoplankton at selected stations, representing a spectrum of values in main areas of the lagoon of Venice, Italy. Tr: Secchi disk transparency, as depth (m)

\begin{tabular}{|c|c|c|c|c|c|c|c|c|c|c|c|c|c|}
\hline \multirow{3}{*}{$\begin{array}{l}\text { Terrip. } \\
\left({ }^{\circ} \mathrm{C}\right)\end{array}$} & \multirow{3}{*}{$\begin{array}{c}\text { Salinity } \\
(\% \circ)\end{array}$} & \multirow[t]{3}{*}{$\operatorname{Tr}$} & \multirow[t]{3}{*}{ Stn } & \multirow{3}{*}{$\begin{array}{l}\text { Depth } \\
\text { (m) }\end{array}$} & \multirow{2}{*}{\multicolumn{2}{|c|}{$\begin{array}{l}\text { Microalgae } \\
>30 \mu \mathrm{m}\end{array}$}} & \multirow{2}{*}{\multicolumn{2}{|c|}{$\begin{array}{l}\text { Nanoalgae } \\
30-3 \mu \mathrm{m}\end{array}$}} & \multicolumn{3}{|c|}{ Picoalgae 3-1 $\mu \mathrm{m}$} & & \multirow{3}{*}{$\begin{array}{l}\text { Total biomass } \\
\text { of phyto- } \\
\text { plankton } \\
\left(\mathrm{mg} \mathrm{m}^{-3}\right)\end{array}$} \\
\hline & & & & & & & & & $\begin{array}{l}\text { Eucary- } \\
\text { otic }\end{array}$ & & $\begin{array}{l}\text { Cyano- } \\
\text { bacteria }\end{array}$ & & \\
\hline & & & & & $\left(\mathrm{N} \times 10^{3}\right)$ & $\mathrm{B}$ & $\left(\mathrm{N} \times 10^{6}\right)$ & $B$ & $\left(\mathrm{~N} \times 10^{6}\right.$ & $B$ & $\left(\mathrm{~N} \times 10^{6}\right)$ & $B$ & \\
\hline \multicolumn{14}{|c|}{ Malamocco-Chioggia } \\
\hline $20-22$ & $36-37$ & Bottom & 1 & 2.2 & 1.0 & 32 & 21.9 & 485 & 75 & 105 & 110 & 45 & 657 \\
\hline $20-22$ & $36-37$ & Bottom & 2 & 2.3 & 0.6 & 17 & 10.8 & 323 & 35 & 52 & 108 & 44 & 437 \\
\hline $20-22$ & $36-37$ & Bottom & 3 & 2.0 & 0.6 & 10 & 3.8 & 133 & 29 & 43 & 32 & 13 & 199 \\
\hline $20-22$ & $36-37$ & Bottom & 4 & 2.5 & 0.5 & 10 & 17.1 & 461 & 63 & 95 & $<2$ & $<1$ & 565 \\
\hline $20-22$ & $36-37$ & Bottom & 5 & 2.0 & $<0.5$ & $<10$ & 7.9 & 274 & 46 & 67 & $<1$ & $<1$ & 344 \\
\hline $20-22$ & $36-37$ & Bottom & 6 & 1.7 & 3.0 & 46 & 2.2 & 67 & 11 & 17 & 47 & 20 & 150 \\
\hline $20-22$ & $36-37$ & Bottom & 7 & 1.0 & $<0.5$ & $<10$ & 3.5 & 1.70 & $<1$ & 7 & 38 & 1.7 & 197 \\
\hline \multicolumn{14}{|c|}{ Palude della Rosa } \\
\hline $19-21$ & $28-32$ & Bottom & 8 & 1.0 & $<0.5$ & $<10$ & 2.9 & 109 & 13 & 2.5 & $<1$ & $<1$ & 137 \\
\hline $19-21$ & $28-32$ & Bottom & 9 & 1.0 & $<0.5$ & $<10$ & 3.8 & 100 & 38 & 57 & $<1$ & $<2$ & 1.57 \\
\hline $19-21$ & $28-32$ & Bottom & 10 & 1.0 & $<0.5$ & $<10$ & 3.8 & 89 & 44 & 65 & $<1$ & $<2$ & 154 \\
\hline $19-21$ & $28-32$ & Bottom & 11 & 1.2 & $<0.5$ & $<10$ & 3.8 & 89 & 32 & 47 & $<1$ & $<2$ & 136 \\
\hline $19-21$ & $28-32$ & Bottom & 12 & 1.0 & $<0.5$ & $<10$ & 6.3 & 146 & 54 & 89 & $<1$ & $<1$ & 238 \\
\hline $19-21$ & $28-32$ & Bottom & 13 & 1.3 & $<0.5$ & $<10$ & 5.7 & 125 & 13 & 25 & $<1$ & $<2$ & 150 \\
\hline \multicolumn{14}{|c|}{ Marghera - Malamocco - Alberoni } \\
\hline $18-20$ & $29-35$ & $0.9-1.6$ & 14 & 2.0 & $<0.3$ & $<0.5$ & 5.2 & 99 & 14 & 28 & 10 & 25 & 152 \\
\hline $18-20$ & $29-35$ & $0.9-1.6$ & 15 & 6.0 & $<0.3$ & $<0.5$ & 3.3 & 100 & 19 & 38 & $<1$ & 5 & 145 \\
\hline $18-20$ & $29-35$ & $0.9-1.6$ & 16 & 2.0 & $<0.3$ & $<0.5$ & 2.4 & 90 & 12 & 25 & $<1$ & $<2$ & 116 \\
\hline $18-20$ & $29-35$ & $0.9-1.6$ & 17 & 3.0 & $<0.3$ & $<0.5$ & 3.6 & 88 & 19 & 40 & $<1$ & $<2$ & 129 \\
\hline $18-20$ & $29-35$ & $0.9-1.6$ & 18 & 3.0 & $<0.3$ & $<0.5$ & 4.5 & 106 & 21 & 42 & $<1$ & $<1$ & 149 \\
\hline $18-20$ & $29-35$ & $0.9-1.6$ & 19 & 3.0 & $<0.3$ & $<0.5$ & 8.4 & 200 & 18 & 23 & $<1$ & $<2$ & 224 \\
\hline $18-20$ & $29-35$ & $0.9-1.6$ & 20 & 2.0 & $<0.3$ & $<0.5$ & 3.7 & 106 & 19 & 38 & $<1$ & $<2$ & 144 \\
\hline $18-20$ & $29-35$ & $0.9-1.6$ & 21 & 5.0 & $<0.3$ & $<0.5$ & 7.0 & 146 & 21 & 32 & $<1$ & $<2$ & 178 \\
\hline $18-20$ & $29-35$ & $0.9-1.6$ & 22 & 7.0 & $<0.3$ & $<0.5$ & 6.3 & 166 & 33 & 43 & $<1$ & 5 & 209 \\
\hline \multicolumn{14}{|c|}{ Venice - Murano - Lido } \\
\hline $19-20$ & $33-37$ & $0.8-1.3$ & 23 & 5.0 & $<0.5$ & $<10$ & 4.2 & 103 & 14 & 26 & 2.4 & 5 & 134 \\
\hline $19-20$ & $33-37$ & $0.8-1.3$ & 24 & 3.0 & $<0.5$ & $<10$ & 11.6 & 250 & 24 & 48 & $<1$ & $<1$ & 307 \\
\hline $19-20$ & $33-37$ & $0.8-1.3$ & 25 & 7.0 & $<0.5$ & $<10$ & 5.7 & 143 & 19 & 38 & $<1$ & $<2$ & 196 \\
\hline $19-20$ & $33-37$ & $0.8-1.3$ & 26 & 4.0 & $<0.5$ & $<10$ & 3.9 & 71 & 15 & 30 & $<1$ & $<1$ & 106 \\
\hline $19-20$ & $33-37$ & $0.8-1.3$ & 27 & 5.0 & $<0.5$ & $<10$ & 5.4 & 133 & 14 & 28 & $<1$ & $<2$ & 166 \\
\hline $19-20$ & $33-37$ & $0.8-1.3$ & 28 & 5.0 & $<0.5$ & $<10$ & 3.9 & 87 & 17 & 33 & $<1$ & $<\overline{2}$ & 125 \\
\hline $19-20$ & $33-37$ & $0.8-1.3$ & 29 & 4.0 & $<0.5$ & $<10$ & 6.4 & 179 & 14 & 28 & $<1$ & $<2$ & 212 \\
\hline $19-20$ & $33-37$ & $0.8-1.3$ & 30 & 6.0 & $<0.5$ & $<10$ & 2.6 & 62 & 17 & 34 & $<1$ & $<1$ & 100 \\
\hline $19-20$ & $33-37$ & $0.8-1.3$ & 31 & 4.0 & $<0.5$ & $<10$ & 3.8 & 64 & 22 & 43 & $<1$ & $<2$ & 112 \\
\hline $19-20$ & $33-37$ & $0.8-1.3$ & 32 & 3.0 & $<0.5$ & $<10$ & 3.6 & 73 & 17 & 34 & $<1$ & $<2$ & 112 \\
\hline $19-20$ & $33-37$ & $0.8-1.3$ & 33 & 4.0 & $<0.5$ & $<10$ & 2.3 & 41 & 19 & 38 & $<1$ & $<2$ & 84 \\
\hline $19-20$ & $33-37$ & $0.8=1.3$ & 34 & 3.0 & $<0.5$ & $<10$ & 2.4 & 53 & 30 & 30 & $<1$ & $<1$ & 86 \\
\hline $19-20$ & $33-37$ & $0.8-13$ & 35 & 3.0 & $<0.5$ & $<10$ & 2.0 & 40 & 19 & 38 & $<1$ & $<2$ & 78 \\
\hline \multicolumn{2}{|c|}{ Adriatic Sea } & 3.0 & 36 & 15.0 & 1.2 & 15 & 5.5 & 145 & 54 & 54 & $<1$ & $<1$ & 252 \\
\hline
\end{tabular}




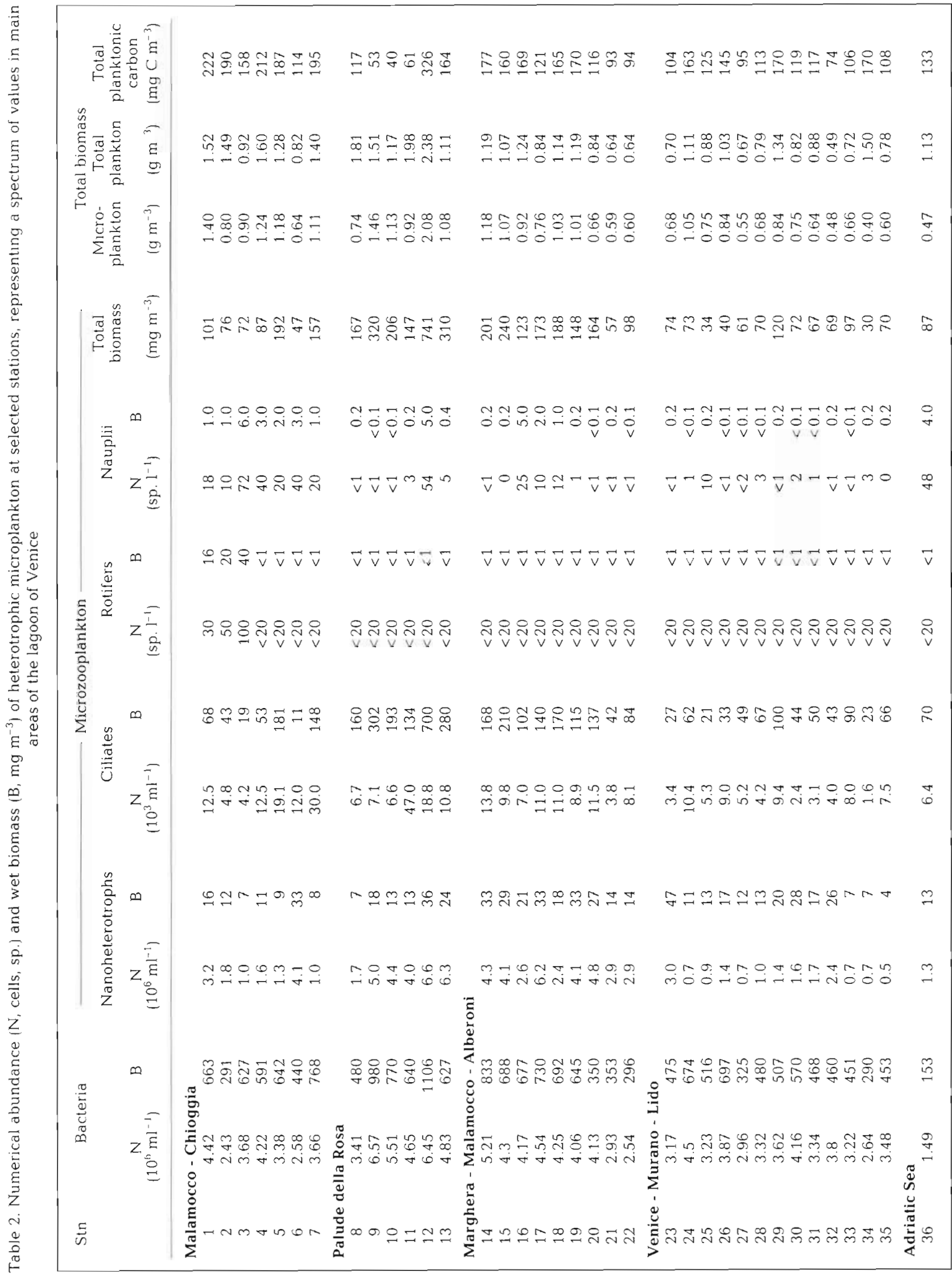


Table 3. Numerical abundance $\left(\mathrm{N}, 10^{3} \mathrm{~m}^{-3}\right)$, wet biomass of main components of mesozooplankton $\left(\mathrm{B}, \mathrm{mg} \mathrm{m} \mathrm{m}^{-3}\right)$, and total plankton biomass at stations in main areas of the lagoon of Venice

\begin{tabular}{|c|c|c|c|c|c|c|c|c|c|c|c|}
\hline \multirow[t]{3}{*}{ Str } & \multirow{2}{*}{\multicolumn{2}{|c|}{$\begin{array}{l}\text { Copepods } \\
\text { Small cyclopids } \\
\text { and copepods }\end{array}$}} & \multirow{2}{*}{\multicolumn{2}{|c|}{$\begin{array}{l}\text { Adult } \\
\text { calanids }\end{array}$}} & \multirow{2}{*}{\multicolumn{2}{|c|}{ Cladocerans (Penilia) }} & \multirow{2}{*}{\multicolumn{2}{|c|}{ Zoea and mysids }} & \multirow{2}{*}{\multicolumn{2}{|c|}{ Sagitta }} & \multirow{3}{*}{$\begin{array}{l}\text { Total } \\
\text { blomass } \\
\left(\mathrm{mg} \mathrm{m}^{-3}\right)\end{array}$} \\
\hline & & & & & & & & & & & \\
\hline & $N$ & B & $N$ & $B$ & $N$ & $B$ & N & $B$ & $N$ & B & \\
\hline \multicolumn{12}{|c|}{ Malamocco-Chioggia } \\
\hline 1 & 4.1 & 29 & 1.40 & 36 & 1.40 & 51 & 0.00 & 0 & 0.00 & 0 & 116 \\
\hline 2 & 35.0 & 280 & 1.20 & 33 & 10.60 & 380 & 0.00 & 0 & 0.00 & 0 & 694 \\
\hline 3 & 8.5 & 70 & 0.20 & 6 & 0.00 & 0 & 1.15 & 160 & 0.00 & 0 & 236 \\
\hline 4 & 16.6 & 50 & 6.50 & 200 & 0.00 & 0 & 0.10 & 14 & 0.00 & 0 & 264 \\
\hline 5 & 16.0 & 50 & 0.50 & 15 & 0.00 & 0 & 0.20 & 30 & 0.00 & 0 & 95 \\
\hline 6 & 9.8 & 48 & 0.80 & 28 & 0.00 & 0 & 0.00 & 0 & 0.10 & 20 & 176 \\
\hline 7 & 1.5 & 12 & 8.60 & 120 & 2.60 & 80 & 0.00 & 0 & 0.03 & 8 & 280 \\
\hline \multicolumn{12}{|c|}{ Palude della Rosa } \\
\hline 8 & 4.0 & 36 & 0.70 & 22 & 3.90 & 2 & 0.00 & 0 & 0.00 & 0 & 60 \\
\hline 9 & 3.1 & 40 & 0.20 & 6 & 0.05 & 2 & 0.00 & 0 & 0.00 & 0 & 48 \\
\hline 10 & 2.7 & 30 & 0.20 & 6 & 0.05 & 0 & 0.00 & 0 & 0.00 & 0 & 36 \\
\hline 11 & 6.0 & 48 & 0.20 & 6 & 0.00 & 0 & 0.00 & 0 & 0.00 & 0 & 55 \\
\hline 12 & 22.5 & 290 & 0.10 & 3 & 0.03 & 1 & 0.00 & 0 & 0.00 & 0 & 293 \\
\hline 13 & 2.3 & 16 & 0.06 & 17 & 0.00 & 0 & 0.00 & 0 & 0.00 & 0 & 33 \\
\hline \multicolumn{12}{|c|}{ Marghera - Malamocco - Alberoni } \\
\hline 14 & 0.3 & 2 & 0.07 & 2 & 0.00 & 0 & 0.00 & 0 & 0.00 & 0 & 4 \\
\hline 15 & 0.0 & 0 & 0.00 & 0 & 0.00 & 0 & 0.00 & 0 & 0.00 & 0 & 0 \\
\hline 16 & 35.0 & 280 & 1.60 & 40 & 0.00 & 0 & 0.00 & 0 & 0.00 & 0 & 320 \\
\hline 17 & 8.0 & 50 & 0.40 & 10 & 0.00 & 0 & 0.10 & 15 & 0.00 & 0 & 75 \\
\hline 18 & 10.0 & 70 & 1.40 & 40 & 0.00 & 0 & 0.00 & 0 & 0.00 & 0 & 110 \\
\hline 19 & 16.2 & 130 & 0.60 & 18 & 0.07 & 3 & 0.00 & 0 & 0.00 & 30 & 181 \\
\hline 20 & 14.8 & 110 & 1.35 & 38 & 0.60 & 20 & 0.00 & 0 & 0.12 & 8 & 76 \\
\hline 21 & 0.4 & 5 & 1.42 & 40 & 0.00 & 0 & 0.00 & 0 & 0.03 & 0 & 45 \\
\hline 22 & 2.0 & 16 & 0.60 & 20 & 0.10 & 4 & 0.00 & 0 & 6.00 & 0 & 40 \\
\hline \multicolumn{12}{|c|}{ Venice - Murano - Lido } \\
\hline 23 & 06 & 6 & 0.03 & 1 & 0.03 & 1 & 000 & 0 & 0.00 & 8 & 16 \\
\hline 24 & 4.8 & 36 & 0.30 & 10 & 0.00 & 0 & 0.00 & 0 & 0.03 & 18 & 64 \\
\hline 25 & 12.3 & 100 & 0.80 & 22 & 0.00 & 0 & 0.00 & 0 & 0.08 & 8 & 131 \\
\hline 26 & 9.1 & 90 & 2.20 & 70 & 0.00 & 0 & 0.20 & 32 & 0.00 & 0 & 192 \\
\hline 27 & 6.8 & 80 & 1.50 & 40 & 0.00 & 0 & 0.00 & 0 & 0.00 & 0 & 120 \\
\hline 28 & 6.0 & 70 & 0.90 & 27 & 0.20 & 4 & 0.00 & 0 & 0.03 & 10 & 111 \\
\hline 29 & 27.9 & 280 & 3.30 & 105 & 0.00 & 0 & 0.22 & 48 & 0.22 & 58 & 491 \\
\hline 30 & 5.1 & 41 & 1.30 & 32 & 0.00 & 0 & 0.00 & 0 & 0.00 & 0 & 73 \\
\hline 31 & 15.6 & 150 & 2.00 & 55 & 0.00 & 0 & 0.00 & 0 & 0.06 & 20 & 225 \\
\hline 32 & 1.2 & 10 & 0.08 & 2 & 0.00 & 0 & 0.00 & 0 & 0.00 & 0 & 12 \\
\hline 33 & 7.5 & 60 & 0.08 & 2 & 0.00 & 0 & 0.00 & 0 & 0.00 & 0 & 62 \\
\hline 34 & 51.2 & 460 & 21.00 & 530 & 0.50 & 18 & 0.06 & 23 & 0.30 & 80 & 1111 \\
\hline 35 & 13.5 & 108 & 2.10 & 60 & 6.00 & 0 & 0.00 & 0 & 0.03 & 8 & 76 \\
\hline \multicolumn{12}{|c|}{ Adriatic Sea } \\
\hline 36 & 21.2 & 170 & 15.00 & 375 & 1.50 & 45 & 0.00 & 0 & 0.12 & 32 & 622 \\
\hline
\end{tabular}

was found in the less polluted Malamocco-Chioggia area. The fraction of $>30 \mu \mathrm{m}$ microalgae often had a lower share of the total phytoplankton biomass. Only in the abovementioned area did it comprise 4 to $30 \%$ of the total biomass, while in other areas the quota of larger algae, especially diatoms, was negligible - less than 2 to $3 \%$ of the total phytoplankton biomass. This fraction was mainly represented by dinoflagellates (Peridinium, Gymnodinium, Ceratium) and a variety of diatom species. The total phytoplankton biomass was largest in the Malamocco-Chioggia area, where it reached 300 to $600 \mathrm{mg} \mathrm{m}^{-3}$. In other areas it varied between 100 and $200 \mathrm{mg} \mathrm{m}^{-3}$, being lower in the Murano-Lido area ( 75 to $112 \mathrm{mg} \mathrm{m}^{-3}$ at Stns 31 to 35 ).
At Stn 36 in the Adriatic, its biomass was moderate (252 $\mathrm{mg} \mathrm{m}^{-3}$ ), also being dominated there by nano- and picophytoflagellates.

The total number of planktonic bacteria in all the waters of the lagoon was very high. In the northern sub-lagoon of Palude della Rosa, it reached a peak of 3.4 to $6.5 \times 10^{6} \mathrm{ml}^{-1}$ (Table 2). In the Marghera-Malamocco area it was 3 to $5 \times 10^{6} \mathrm{ml}^{-1}$. Around Venice and in the southern part of the lagoon, it ranged between 2.5 and $4.4 \times 10^{6} \mathrm{ml}^{-1}$. At Stn 36 in the Adriatic, it was about half: $1.5 \times 10^{6} \mathrm{ml}^{-1}$. The average volume of bacterial cells was 0.15 to $0.20 \mu^{-3}$. The wet bacterioplankton biomass at most stations ranged between 300 and $600 \mathrm{mg} \mathrm{m}^{-3}$ ( 60 to $120 \mathrm{mg} \mathrm{C} \mathrm{m}^{-3}$ ). The protozoan frac- 
Table 4. Standing stock measurements and dynamic parameters at selected stations, representing a spectrum in main areas of the lagoon of Venice. KS: contents of labile sulfides in upper layer of bottom sediments; LOM, SOM: contents of labile and suspended organic matter in water; PP: primary production of organic matter by phytoplankton $\mathrm{d}^{-1}$; BP: production of bacterioplankton $\mathrm{d}^{-1}$; $\mathrm{MB}$ : calculated respiration of bacterioplankton $\mathrm{d}^{-1}$; TM: total plankton respiration $\mathrm{d}^{-1}$

\begin{tabular}{|c|c|c|c|c|c|c|c|c|c|c|}
\hline \multirow[t]{2}{*}{ Stn } & \multirow{2}{*}{$\begin{array}{l}\text { Depth } \\
(\mathrm{m})\end{array}$} & \multicolumn{3}{|c|}{ Standing stocks } & \multicolumn{3}{|c|}{ Dynamics } & \multicolumn{3}{|c|}{ Respiration } \\
\hline & & $\begin{array}{c}\mathrm{KS} \\
\left(\mathrm{mg} \mathrm{S} \mathrm{dm}^{-3}\right)\end{array}$ & $\begin{array}{c}\text { LOM } \\
\left(\mathrm{mg} \mathrm{Cl}^{-1}\right)\end{array}$ & $\begin{array}{c}\mathrm{SOM} \\
\left(\mathrm{mgCl}^{-1}\right)\end{array}$ & $\left(\mathrm{mgC} \mathrm{m}^{-3}\right)^{\mathrm{P}}$ & $\begin{array}{l}\mathrm{pP} \\
\left(\mathrm{mg} \mathrm{C} \mathrm{m} \mathrm{m}^{-2}\right)\end{array}$ & $\begin{array}{c}\mathrm{BP} \\
\left(\mathrm{mg} \mathrm{C} \mathrm{m} \mathrm{m}^{-3}\right)\end{array}$ & $\begin{array}{c}\mathrm{MB} \\
\left(\mathrm{mg} \mathrm{C} \mathrm{m}^{-3}\right)\end{array}$ & $\left(\mathrm{mg} \mathrm{O}_{2} 1^{-1}\right)$ & ( $\left(\mathrm{mg} \mathrm{C} \mathrm{m}^{-2}\right)$ \\
\hline \multicolumn{11}{|c|}{ Malamocco-Chioggia } \\
\hline 1 & 2 & 270 & 1.71 & 0.68 & 67 & 150 & 43 & 91 & 0.40 & 330 \\
\hline 2 & 2 & 135 & 1.50 & 0.72 & 59 & 80 & 35 & 74 & 0.53 & 450 \\
\hline 4 & 2 & 162 & 1.82 & 0.90 & 54 & 190 & 36 & 71 & 0.50 & 470 \\
\hline 7 & 1 & 320 & 1.54 & 1.18 & 22 & 20 & 48 & 102 & 0.56 & 210 \\
\hline \multicolumn{11}{|c|}{ Palude della Rosa } \\
\hline 8 & 1 & - & 2.84 & 2.10 & 27 & 30 & 29 & 62 & 0.23 & 86 \\
\hline 10 & 1 & - & 1.80 & 0.88 & 21 & 20 & 35 & 74 & 0.28 & 105 \\
\hline 12 & 1 & - & 2.11 & 1.49 & 34 & 40 & 40 & 85 & 0.29 & 140 \\
\hline \multicolumn{11}{|c|}{ Marghera - Malamocco - Alberoni } \\
\hline 14 & 2 & 530 & 3.37 & 1.31 & 37 & 50 & 18 & 38 & 0.92 & 690 \\
\hline 15 & 6 & 970 & 2.93 & 2.19 & 13 & 20 & 68 & 144 & 0.98 & 2200 \\
\hline 17 & 3 & 1940 & 3.04 & 1.03 & 36 & 70 & 30 & 63 & 0.74 & 830 \\
\hline 18 & 3 & 2300 & 3.09 & 0.95 & 42 & 50 & 24 & 51 & 0.92 & 1035 \\
\hline 20 & 2 & 760 & 2.06 & 1.33 & 24 & 30 & 22 & 46 & 0.53 & 1060 \\
\hline 21 & 5 & 1530 & 2.16 & 3.47 & 22 & 30 & 31 & 66 & 0.57 & 1060 \\
\hline \multicolumn{11}{|c|}{ Venice - Murano - Lido } \\
\hline 23 & 5 & 1700 & 3.10 & 3.24 & 19 & 30 & 36 & 77 & 0.34 & 640 \\
\hline 26 & 4 & 1360 & 3.06 & 1.21 & 21 & 30 & 39 & 83 & 1.54 & 2300 \\
\hline 27 & 5 & 480 & 2.60 & 0.73 & 31 & 60 & 22 & 46 & 0.56 & 1050 \\
\hline 29 & 4 & 1250 & 3.00 & 1.24 & 43 & 50 & 31 & 66 & 0.43 & 720 \\
\hline 31 & 4 & 870 & 2.22 & 0.90 & 32 & 40 & 36 & 77 & 0.43 & 640 \\
\hline \multicolumn{11}{|c|}{ Adriatic Sea } \\
\hline 36 & 15 & - & 1.07 & 0.45 & 41 & 250 & 17 & 36 & 0.19 & 1060 \\
\hline
\end{tabular}

tion of microzooplankton included nanoheterotrophs and ciliates, the former represented by 2 to $5 \mu \mathrm{m}$ phagotrophic zooflagellates. Their number varied between 0.5 and $5 \times 10^{6}$ cells $1^{-1}$ (Table 2). At some stations they attained a significant biomass of 20 to $40 \mathrm{mg} \mathrm{m}^{-3}$, thus comprising 10 to $40 \%$ of the total protozoan biomass. Most of their population was represented by the genera Bodo, Parabodo and Monas. Planktonic ciliates were most abundant in the sub-lagoon of Palude della Rosa, together with abundant bacterioplankton, attaining a biomass of $700 \mathrm{mg} \mathrm{m}^{-3}$ (range: 160 to $700 \mathrm{mg} \mathrm{m}^{-3}$ ). A significant density of ciliates, up to $420 \mathrm{mg} \mathrm{m}^{-3}$, was recorded in the central part of the lagoon, influenced by the Marghera industrial zone. On the whole, at many stations, especially in areas subjected to pollution from Marghera and Venice, the ciliate biomass was more than that of mesozooplankton. The number of ciliates varied here between 2 and $14 x$ $10^{3} \mathrm{I}^{-1}$. The most common genera were Strombidium, Tontonia, Tiarina and Mesodinium pulex. The biomass of multicellular microzooplankton, represented by rotifers and nauplii, was significant only in the southern, cleaner part of the lagoon (Stns 1 to 3; Table 2), where it reached 10 to $46 \mathrm{mg} \mathrm{m}^{-3}$. The total microzooplankton biomass ranged between 70 and $240 \mathrm{mg} \mathrm{m}^{-3}$. Only at Stn 12 was it $741 \mathrm{mg} \mathrm{m}^{-3}$. Average values (Table 5) were comparable with those of mesozooplankton. In the Palude della Rosa and the polluted VeniceMarghera area, where mesozooplankton was inhibited by water turbidity and chemical pollution, its biomass was depressed to $1 / 2$ to $1 / 3$ that of planktonic protozoa.

Mesozooplankton attained a biomass close to $500 \mathrm{mg}$ $\mathrm{m}^{-3}$ and more at only 3 stations situated in areas closely connected with the sea (Strus 2, 29 and 34; Table 3). In the sea (Stn 36) it was $623 \mathrm{mg} \mathrm{m}^{-3}$. In about half of the 35 stations, the biomass of mesozooplankton was less than $100 \mathrm{mg} \mathrm{m}^{-3}$. At Stns 14 and 15, directly influenced by pollution from industrial and port zones, it fell to $16 \mathrm{mg} \mathrm{m}^{-3}$ or less. The copepods at these stations were blackish in color, and many were dead or evidently injured. Much of the total mesozooplankton at most stations was composed of calanoid copepods. Numerically, small calanoid copepods and 300 to $600 \mu \mathrm{m}$ cyclopids were most abundant. At several stations in areas directly connected with the sea, as well as in the sea itself, the cladoceran Penilia was found in significant amounts: up to $3-10 \times 10^{3} \mathrm{~m}^{-3}$ (biomass: 100 to $380 \mathrm{mg} \mathrm{m}^{-3}$ ). Lower amounts of Sagitta (30 to

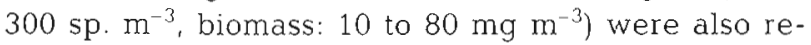
corded at several stations. At Stns 3 to 5, close to mussel aquaculture fields, zoea and small mysids were recorded, with biomasses from 40 to $160 \mathrm{mg} \mathrm{m}^{-3}$. The 
Table 5. Averages of some basic parameters and ratios calculated for all stations in given areas of the lagoon of Venice. Abbreviations as in Table 4

\begin{tabular}{|c|c|c|c|c|c|}
\hline Parameter & $\begin{array}{l}\text { Chioggia - } \\
\text { Malamocco }\end{array}$ & $\begin{array}{l}\text { Palude } \\
\text { della } \\
\text { Rosa }\end{array}$ & $\begin{array}{c}\text { Marghera - } \\
\text { Malamocco - } \\
\text { Alberoni }\end{array}$ & $\begin{array}{l}\text { Venice - } \\
\text { Murano - } \\
\text { Lido }\end{array}$ & Adriatic Sea \\
\hline \multicolumn{6}{|l|}{ Environmental characteristics } \\
\hline Water temperature $\left({ }^{\circ} \mathrm{C}\right)$ & $20-22$ & $19-21$ & $18-20$ & $19-20$ & 18 \\
\hline Secchi disk transparency $(\mathrm{m})$ & To bottom & To bottom & $0.9-1.6$ & $0.8-1.3$ & 3.0 \\
\hline Salinity $(\%)$ & $36-37$ & $28-32$ & $29-35$ & $33-37$ & 37 \\
\hline Number of stations (for calculation of average) & 7 & 6 & 9 & 13 & 1 \\
\hline \multicolumn{6}{|l|}{ Biomass (B) (wet weight, $\mathrm{mg} \mathrm{m}^{-3}$ ) } \\
\hline Phytoplankton & 360 & 160 & 160 & 140 & 252 \\
\hline Bacterioplankton & 570 & 770 & 580 & 460 & 153 \\
\hline Microzooplankton & 104 & 315 & 154 & 67 & 87 \\
\hline Mesozooplankton & 265 & 87 & 95 & 206 & 623 \\
\hline Total plankton & 1300 & 1660 & 980 & 900 & 1100 \\
\hline \multicolumn{6}{|l|}{ Production ( $\mathrm{mg} \mathrm{C} \mathrm{m} \mathrm{m}^{-2} \mathrm{~d}^{-1}$ ) } \\
\hline Phytoplankton & 87 & 30 & 40 & 50 & 250 \\
\hline Bacterioplankton & 76 & 38 & 120 & 140 & 255 \\
\hline \multicolumn{6}{|l|}{ Respiration $\left(d^{-1}\right)$} \\
\hline \multirow{2}{*}{$\begin{array}{ll}\text { Total plankton } & \mathrm{mg} \mathrm{O}_{2} \mathrm{l}^{-1} \\
\mathrm{gC} \mathrm{Cm}^{-2} & (\mathrm{TM})\end{array}$} & 0.45 & 0.26 & 0.75 & 0.60 & 0.19 \\
\hline & 0.327 & 0.101 & 1.010 & 0.840 & 1.060 \\
\hline Bacterioplankton $\mathrm{g} \mathrm{C} \mathrm{m}^{-2}(\mathrm{MB})$ & 0.160 & 0.080 & 0.286 & 0.284 & 0.540 \\
\hline \multicolumn{6}{|l|}{ Standing stock } \\
\hline \multicolumn{6}{|l|}{ Organic matter in water ( $\mathrm{mg} \mathrm{Cl}^{-1}$ ) } \\
\hline Labile (LOM) & 1.8 & 2.1 & 2.8 & 2.5 & 1.07 \\
\hline Suspended $(\mathrm{SOM})$ & 0.83 & 1.47 & 1.50 & 2.13 & 1.65 \\
\hline Labile sulfides in sediments $\left(\mathrm{mg} \mathrm{S}^{2-} \mathrm{dm}^{-3}\right.$ ) & 280 & - & 1230 & 840 & - \\
\hline \multicolumn{6}{|l|}{ Specific production $\left(\mathrm{P} / \mathrm{B} \mathrm{d}^{-1}\right)$} \\
\hline Phytoplankton (in upper layer) & 1.5 & 2.2 & 2.2 & 3.2 & 2.0 \\
\hline Bacterioplankton & 0.4 & 0.2 & 0.4 & 0.3 & 0.6 \\
\hline \multicolumn{6}{|l|}{ Shares $(\%)$} \\
\hline Heterotrophs in total microplankton biomass & 70 & 84 & 81 & 75 & 67 \\
\hline Microplankton in total plankton biomass & 82 & 93 & 89 & 72 & 43 \\
\hline Living matter in suspended organic matter & 23 & 15 & 9 & 11 & 30 \\
\hline \multicolumn{6}{|l|}{ Ratios } \\
\hline $\mathrm{BP} / \mathrm{PP}$ & 0.87 & 1.27 & 3.00 & 2.80 & 1.02 \\
\hline $\mathrm{TM} / \mathrm{PP}$ & 3.8 & 3.4 & 25.2 & 16.8 & 4.2 \\
\hline LOM/TB (turnover time, d) & 11 & 23 & 11 & 15 & 15 \\
\hline $\mathrm{MB} / \mathrm{TB}$ & 0.49 & 0.79 & 0.25 & 0.34 & 0.51 \\
\hline
\end{tabular}

average mesozooplankton biomass in the main areas of the lagoon varied within the same range of 87 to $265 \mathrm{mg} \mathrm{m}^{-3}$, like that of microzooplankton (Table 5).

The total plankton biomass at most stations was composed mainly of the microplankton fraction, including phytoplankton, bacteria and microzooplankton, It comprised 60 to $90 \%$ of the total plankton biomass at most stations, except areas in close contact with the sea via the port entrances (Stns 2, 8, 34; Table 3). The total microplankton biomass characterized the stock of suspended food available for filtering fauna. Its highest level was recorded in the northern and southern parts of the lagoon, where it was over $1 \mathrm{~g} \mathrm{~m}^{-3}$ at most stations (Tables $2 \& 5$ ).

The values of the total plankton biomass are given in Tables $3 \& 5$. The largest values again revealed conditions of less stress by pollution in the northern and southern areas. In the Chioggia-Malamocco (southern) area, the average value was $1.30 \mathrm{~g} \mathrm{~m}^{-3}$, in the Palude della Rosa $1.66 \mathrm{~g} \mathrm{~m}^{-3}$, and in the central part of the lagoon 0.9 to $1 \mathrm{~g} \mathrm{~m}^{-3}$ Expressed in carbon units, the total plankton biomass varied at most stations between 60 and $220 \mathrm{mg} \mathrm{C} \mathrm{m}^{-3}$

\section{Production and respiration rates}

Primary production by phytoplankton in upper layer water in the central, most polluted area was 15 to $25 \mathrm{mg} \mathrm{C} \mathrm{m}^{-3} \mathrm{~d}^{-1}$. In the southern part it was 20 to $67 \mathrm{mg}$ $\mathrm{m}^{-3} \mathrm{~d}^{-1}$, and in the Palude della Rosa 21 to $35 \mathrm{mg} \mathrm{C} \mathrm{m}{ }^{-3}$ $\mathrm{d}^{-1}$. Because of high water turbidity and low average depth (1 to $3 \mathrm{~m}$ ), primary production in the water column in the northern basin was relatively low: 20 to 
$30 \mathrm{mg} \mathrm{C} \mathrm{m} \mathrm{d}^{-2}$. In the southern basin, with more transparent waters, it was several times higher: 80 to $190 \mathrm{mg} \mathrm{C} \mathrm{m} \mathrm{C}^{-1}$. In the central basin around Venice, at stations that were 2 to $5 \mathrm{~m}$ deep, it was 40 to $60 \mathrm{mg}$ $\mathrm{C} \mathrm{m} \mathrm{m}^{-2} \mathrm{~d}^{-1}$. Production of bacterioplankton in carbon units was at about the same level as primary production by phytoplankton, i.e. 20 to $40 \mathrm{mg} \mathrm{C} \mathrm{m}^{-3} \mathrm{~d}^{-1}$, without large deviations among stations (Table 4).

The values of total plankton respiration (TM; Tables 4 \& 5) actually characterize the rate of organic matter decomposition in the water column. In areas less subjected to pollution, it varied between 0.2 and $0.5 \mathrm{mg} \mathrm{O}_{2} \mathrm{l}^{-1} \mathrm{~d}^{-1}$. At stations around Marghera and Venice, it rose to $0.7-1.2 \mathrm{mg} \mathrm{O}_{2} \mathrm{l}^{-1} \mathrm{~d}^{-1}$, while in the Adriatic (Stn 36) it was only $0.19 \mathrm{mg} \mathrm{O}_{2} \mathrm{l}^{-1} \mathrm{~d}^{-1}$. The highest value of $1.54 \mathrm{mg} \mathrm{O}_{2}$ was recorded at Stn 26 , north of Venice. Expressed in carbon units, the TM rates were 100 to $200 \mu \mathrm{g} \mathrm{C} \mathrm{l}^{-1} \mathrm{~d}^{-1}$ in outside areas experiencing direct pollution, but rose to $300-500 \mu \mathrm{g} \mathrm{C}$ $1^{-1} \mathrm{~d}^{-1}$ in polluted areas. Average values calculated per whole water column in the central area of MargheraVenice-Murano were 0.84 and $1.01 \mathrm{~g} \mathrm{C} \mathrm{m}^{-2} \mathrm{~d}^{-1}$, i.e. 15 to 20 times more than primary production, expressed in the same units (Table 5).

\section{Stocks of labile and suspended organic matter in water}

The distribution of labile organic matter (LOM) accessible for immediate microbial consumption and decomposition in various areas of the lagoon clearly reflected the degree of anthropogenic pollution. In areas closer to the sea, farther from Marghera and Venice, the stock of LOM was 1.5 to $2 \mathrm{mg} \mathrm{Cl}^{-1}$, i.e. 1.5 to 2 times greater than in the water of the adjacent Adriatic (Stn 36: $1.07 \mathrm{mg} \mathrm{C}$ ). But in the vicinity of these sources of pollution, it was over $2 \mathrm{mg} \mathrm{Cl}^{-1}$. Peak values of over $3 \mathrm{mg} \mathrm{Cl}^{-1}$ were recorded at Stns 14, 18 and 19 , situated along the pathways of waste discharge from the Marghera industrial zone, and at Stns 23 and 26, in the port area and in the Canal Grande in Venice. The contents of suspended organic matter (SOM) in water were commensurate with those of LOM, ranging from 0.7 to $1.5 \mathrm{mg} \mathrm{Cl}^{-1}$ at most stations (Table 4). The highest values, over $2.5 \mathrm{mg} \mathrm{Cl}^{-1}$, were recorded at Stns 23 , 25 and 21 near Venice and off Marghera.

\section{Stocks of labile sulfides in bottom sediments}

The content of labile (acid-soluble) sulfides in the upper layer of bottom sediments of the lagoon of Venice varied according to pollution impact (Tables 4 $\& 5$ ). The highest concentrations were found in areas directly influenced by wastewater discharge from Marghera and Venice. In the black mud most common in these areas, the contents varied between 530 and $2300 \mathrm{mg} \mathrm{S}^{2-} \mathrm{dm}^{-3}$ of wet silt (average $1230 \mathrm{mg} \mathrm{S} \mathrm{dm}^{-3}$ ). The highest sulfide concentration was recorded at Stn 18 , in an area directly influenced by wastewater discharge from Marghera and known as a point of nocturnal anoxia in summer It was also quite high in the silty sands around Venice and near Marghera: 400 to $700 \mathrm{mg} \mathrm{S} \mathrm{S}^{2-} \mathrm{dm}^{-3}$. The lowest sulfide levels were observed in silty sands dominating the bottom surface in the southern part of the lagoon: 130 to $400 \mathrm{mg}$ $\mathrm{S}^{2-} \mathrm{dm}^{-3}$. The latter value was recorded in the muddy sediment on the channel bed, where the accumulation of detritus stimulates sulfate reduction.

\section{Energy balance and energy flow calculations}

In order to evaluate the functional roles of major components of pelagic communities in the main areas of the lagoon, and to identify anthropogenic transformation, we calculated tentative energy balances of food consumption and utilization. The latter values were then used to construct energy flows between communities and environments, taking into account both the energy of allochthonous organic matter and losses of organic matter due to sedimentation. For this purpose, balances and flows (Figs. 4-9) were calculated for 6 of the most typical stations, in sites subjected to 2 main types of impact influencing the structure of pelagic communities: the level of anthropogenic pollution, and the intensity of water exchange with the sea. For balance calculations, the parameters of biomass and production were used as measured directly at the given stations and expressed in calories: cal $\mathrm{m}^{-2}$ (biomass) or cal m $\mathrm{m}^{-2} \mathrm{~d}^{-1}$ (production). The necessary coefficients of specific production per day $(\mathrm{P} / \mathrm{B})$, efficiency of use of assimilated food for growth $\left(K_{2}\right)$, assimilability of consumed food $(I)$, and caloric equivalents of the wet biomass of plankton (KV) were acquired from the literature (Table 6). The results of balance calculations and the corresponding energy flows are given in Table 7 and Figs. 4-9. Evaluations of amounts of allochthonous organic matter (AL) used in the food web were calculated as an additional energy demand needed to balance the energy budget of the ecosystem (Sorokin 1972).

\section{DISCUSSION}

From the sets of data obtained during the present research, some general conclusions for autumn may be defined. In accordance with previous observations in 


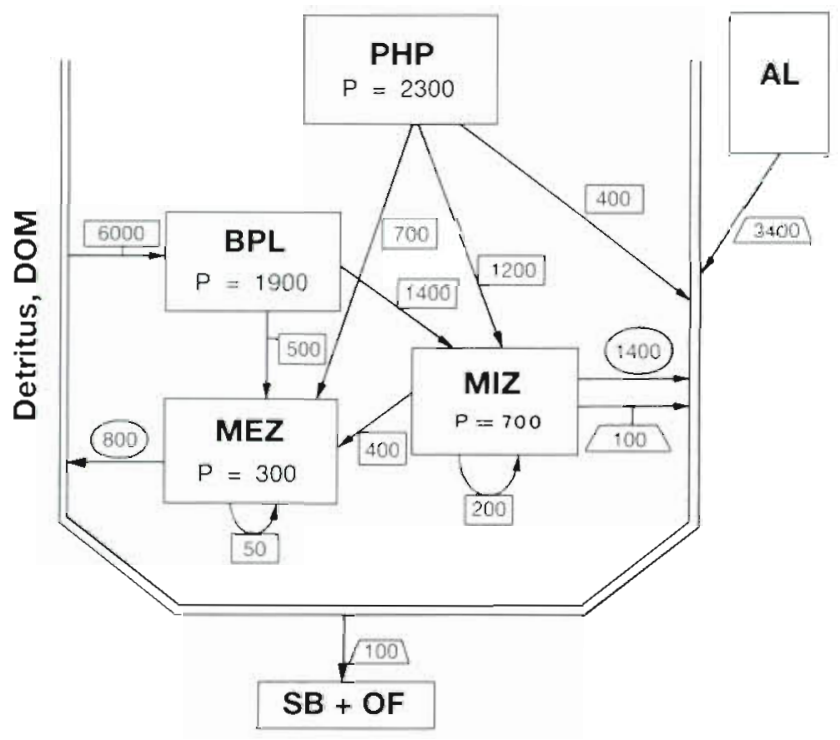

Fig. 4. Energy flows (calories or $\mathrm{cal} \mathrm{m}^{-2} \mathrm{~d}^{-1}$ ) at $\mathrm{Stn} 36$ in Adriatic. Food web components: PHP: phytoplankton, BPL: bacterioplankton; MIZ: microzooplankton; MEZ: mesozooplankton; SB: sedimentation flow to bottom; OF: outflow; DOM: dissolved organic matter; AL: allochthonous organic matter used within pelagic food web. Flows: P: production; numbers in squares: food ration of next component of food web; numbers in circles non-assimilated part of food ration; numbers in trapezıa non-consumed production

the lagoon of Venice and the adjacent Adriatıc, autumn is the season of annual phytoplankton minimum, as indicated by the time course of its biomass or chlorophyll contents in water (Corni et al. 1980, Alberotanza \& Zuc-

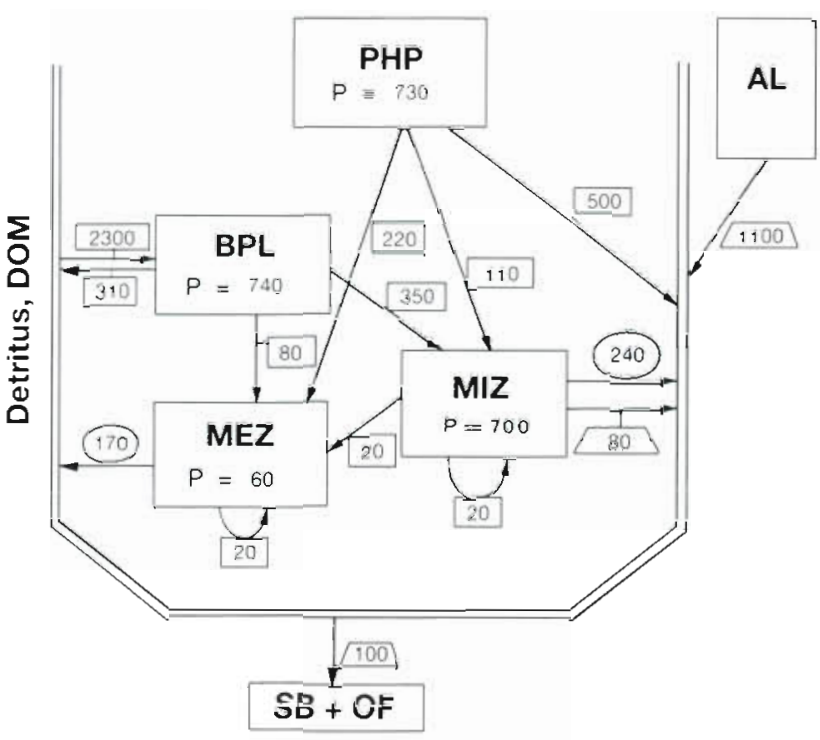

Fig. 5 . Stn 2 in southern basin. Other details as in Fig. 4

chetta 1988, Cairo et al. 1993). Correspondingly, and in accordance with our data, the density of phytoplankton and its primary production were definitely lower than average in this kind of coastal lagoon. From this viewpoint, a usual biomass $>300$ to $500 \mathrm{mg} \mathrm{m}^{-3}$ and quite high primary production (up to $60 \mathrm{mg} \mathrm{C} \mathrm{m}^{-3} \mathrm{~d}^{-1}$ ) were recorded only at a few stations in the southern, less stressed area. The clear inhibition of phytoplankton development in the central area may be attributed to the impact of chemical pollution from Marghera and Venice. This conclusion is supported by data on the

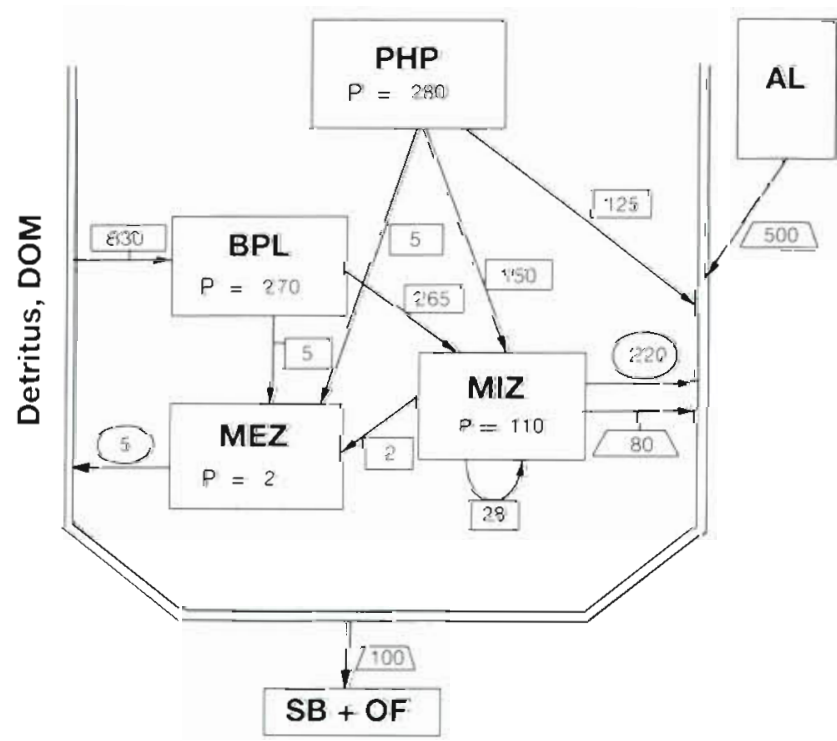

Fig. 6. Stn 8 in northern sub-lagoon of Palude della Rosa. Other details as in Fig. 4

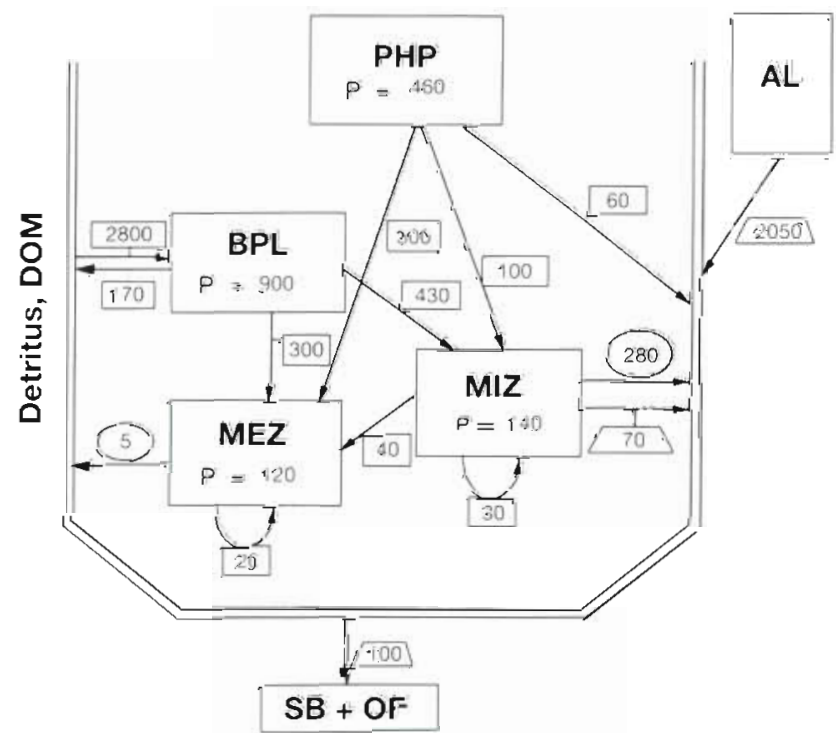

Fig. 7. Sin 34 in central basin, Venice-Lido area. Other details as in Fig. 4 


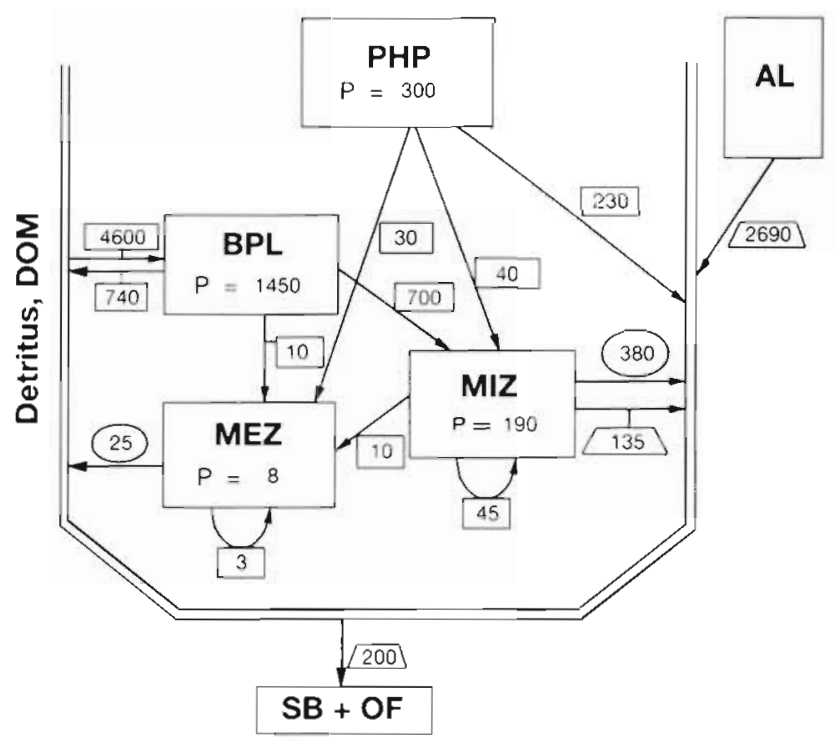

Fig. 8. Stn 21 in central basin, Malamocco-Lido area. Other details as in Fig. 4

composition of the pelagic phytocene. In the central area, this was completely dominated by nano- and picoalgae less sensitive to this impact, while diatoms and dinoflagellates were negligible, being a significant component of phytoplankton biomass only in the cleaner southern basin (Table 1). In the Adriatic (Stn 36) the phytoplankton biomass was moderate $\left(255 \mathrm{mg} \mathrm{m}^{-3}\right)$, being even less than in the Chioggia area.

This study demonstrates the absolute predominance of nano- and picoalgae in the biomass of the pelagic phytocene over larger forms like diatoms and dinoflagellates, which are traditionally recognized as dominant groups in lagoonal waters (Marchesoni 1954, Voltolina 1973, Socal 1979, Socal et al. 1985, Cairo et al. 1993) If this fraction of minute algae is neglected, drastic underestimation of phytoplankton density and incorrect presentation of its composition are the result.

Bacterioplankton is a key component of plankton and an important functional agent in the lagoon (Tables $5 \& 7$ ). Its biomass is 40 to $60 \%$ of the total

Table 6. Coefficients used for energy balance calculations. See text for designations, data according to Sorokin (1982a, b), Edmondson \& Vinberg (1971), Zaika (1973), Grese (1979) and Vinogradov \& Shushkina (1987)

\begin{tabular}{|lcccc|}
\hline Component & $\mathrm{P} / \mathrm{B}$ & $K_{2}$ & $I$ & $\begin{array}{c}\mathrm{KV} \\
\text { (cal mg }\end{array}$ \\
\hline Phytoplankton & - & - & - & 0.60 \\
Bacterioplankton & - & 0.32 & - & - \\
Microzooplankton & 0.80 & 0.50 & 0.50 & 0.85 \\
Mesozooplankton & 0.04 & 0.35 & 0.50 & 0.92 \\
\hline
\end{tabular}

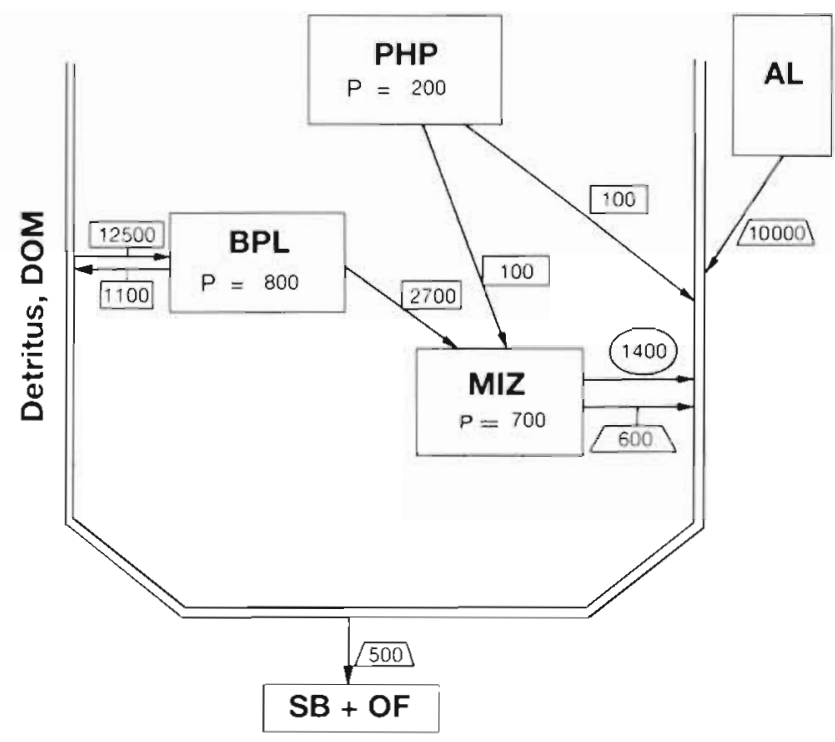

Fig. 9. Stn 15 in central basin, Marghera area. Other details as in Fig. 4

plankton biomass, and is 3 to 5 times greater than that of phytoplankton (Table 5). Its level in the lagoon was 350 to $1100 \mathrm{mg} \mathrm{m}^{-3}$, thus corresponding to upper levels in eutrophic coastal waters (Sorokin 1981). In 1972 it was recorded at the level of 200 to $300 \mathrm{mg} \mathrm{m}^{-3}$ (Sorokin $1975 \mathrm{~b})$. High density of bacterioplankton in lagoonal waters in conditions of rapid grazing by planktonic protozoans can only be supported if bacteria use allochthonous organic matter (Figs, 5-9). Microbial production in the lagoon was at about the same level as primary production in the upper illuminated layer, and, if calculated over the whole water column, was 3 to 6 times greater (see Table 7 ). This means that bacterioplankton creates a large stock of particulate food accessible for planktonic and benthic filtering fauna (including farmed clams). Bacterioplankton is also a main source of food for abundant microzooplankton. The microbial food web created by bacterioplankton with the participation of ciliates and zooflagellates is one of the main driving forces of organic matter degradation in the lagoon. The part played by mesozooplankton in this process in ecologically stressed areas is secondary or negligible. At Stn 15 (Marghera area), this component of the food web was completely obliterated, and self-purification was accomplished exclusively via the microbial food web (see Table $7 \&$ Fig. 9).

The abundant microzooplankton in the lagoon was dominated mostly by naked ciliates, as also proved by its first quantification (Sorokin 1975b). In May 1972, the biomass of planktonic protozoa in the central part of the lagoon attained $700 \mathrm{mg} \mathrm{m}^{-3}$, represented mostly by naked ciliates. The same maximal biomass was recorded in late September 1993 only at Stn 12 in the 
Table 7 Density of populations (biomass, B) and tentative energy balance of food uptake and expenditure in basic types of pelagic ecosystems of areas in the lagoon of Venice, variously stressed by pollution and having various regimes of exchange with adjacent Adriatic. R: food rations; $A$ : assimilated food; $\mathrm{P}$; production; $\mathrm{M}$ : respiration; $F$; non-assimilated part of food ration; Me: medium; L: low; $\mathrm{H}$ : high; all numbers given in cal $\mathrm{m}^{-2} \mathrm{~d}^{-1}$, except biomass, which is given in cal $\mathrm{m}^{-2}$

\begin{tabular}{|c|c|c|c|c|c|c|c|c|c|c|}
\hline \multirow[t]{2}{*}{ Stn } & \multirow[t]{2}{*}{ Location } & \multicolumn{2}{|c|}{ Environment } & \multirow{2}{*}{$\begin{array}{l}\text { Components of } \\
\text { pelagic ecosystem }\end{array}$} & \multirow[t]{2}{*}{ Biomass } & \multicolumn{5}{|c|}{ Elements of energy balance } \\
\hline & & $\begin{array}{l}\text { Level of } \\
\text { pollution }\end{array}$ & $\begin{array}{c}\text { Exchange } \\
\text { with sea }\end{array}$ & & & $\mathrm{R}$ & A & $\mathrm{P}$ & $\mathrm{M}$ & F \\
\hline \multirow[t]{4}{*}{36} & \multirow[t]{4}{*}{ Adriatic Sea } & \multirow[t]{4}{*}{ Me } & \multirow[t]{4}{*}{-} & Phytoplankton & 2300 & 2800 & 2800 & 2300 & 500 & - \\
\hline & & & & Bacterioplankton & 3680 & 6000 & 6000 & 1900 & 4100 & - \\
\hline & & & & Microzooplankton & 900 & 2800 & 1400 & 700 & 1100 & 1400 \\
\hline & & & & Mesozooplankton & 6800 & 1600 & 800 & 300 & 500 & 800 \\
\hline \multirow[t]{4}{*}{2} & \multirow[t]{4}{*}{ Chioggia } & \multirow[t]{4}{*}{ Me } & \multirow[t]{4}{*}{$\mathrm{H}$} & Phytoplankton & 600 & 900 & 900 & 730 & 170 & - \\
\hline & & & & Bacterioplankton & 1230 & 2300 & 2340 & 740 & 1560 & - \\
\hline & & & & Microzooplankton & 150 & 480 & 240 & 120 & 150 & 240 \\
\hline & & & & Mesozooplankton & 1430 & 340 & 170 & 60 & 110 & 170 \\
\hline \multirow[t]{4}{*}{34} & \multirow[t]{4}{*}{ Venice - Lido } & \multirow[t]{4}{*}{$\mathrm{Me}$} & \multirow[t]{4}{*}{$\mathrm{Me}$} & Phytoplankton & 160 & 240 & 550 & 460 & 90 & - \\
\hline & & & & Bacterioplankton & 1600 & 2800 & 2800 & 900 & 1900 & - \\
\hline & & & & Microzooplankton & 170 & 560 & 280 & 140 & 210 & 280 \\
\hline & & & & Mesozooplankton & 3000 & 680 & 340 & 120 & 220 & 340 \\
\hline \multirow[t]{4}{*}{8} & \multirow[t]{4}{*}{ Palude della Rosa } & \multirow[t]{4}{*}{ Me } & \multirow[t]{4}{*}{$\mathrm{L}$} & Phytoplankton & 90 & 340 & 340 & 280 & 50 & - \\
\hline & & & & Bacterioplankton & 900 & 830 & 830 & 270 & 560 & - \\
\hline & & & & Microzooplankton & 140 & 440 & 220 & 110 & 110 & 220 \\
\hline & & & & Mesozooplankton & 60 & 10 & 5 & 2 & 3 & 5 \\
\hline \multirow[t]{4}{*}{21} & \multirow[t]{4}{*}{ Malamocco-Lido } & \multirow[t]{4}{*}{$\mathrm{H}$} & \multirow[t]{4}{*}{ Me } & Phytoplankton & 530 & 360 & 360 & 300 & 60 & - \\
\hline & & & & Bacterioplankton & 3300 & 4600 & 4600 & 1450 & 3150 & - \\
\hline & & & & Microzooplankton & 240 & 740 & 380 & 190 & 190 & 380 \\
\hline & & & & Mesozooplankton & 200 & 50 & 25 & 8 & 17 & 25 \\
\hline \multirow[t]{4}{*}{15} & \multirow[t]{4}{*}{ Marghera } & \multirow[t]{4}{*}{$\mathrm{H}$} & \multirow[t]{4}{*}{$\mathrm{L}$} & Phytoplankton & 420 & 220 & 220 & 200 & 20 & - \\
\hline & & & & Bacterioplankton & 7600 & 12500 & 12500 & 3800 & 8500 & - \\
\hline & & & & Microzooplankton & 900 & 2800 & 1400 & 700 & 700 & 1400 \\
\hline & & & & Mesozooplankton & 0 & 0 & 0 & 0 & 0 & 0 \\
\hline
\end{tabular}

northern basin (Table 2). The range of the microzooplankton biomass at most other stations was within ordinary limits for eutrophic coastal waters: 50 to $300 \mathrm{mg} \mathrm{m}^{-3}$ (Sorokin 1981). The greatest microzooplankton biomass was recorded in the sub-lagoon of the Palude della Rosa, which receives high loads of detritus and microbial biomass with inflowing fresh waters (e.g. the river Dese). The effects of river waters on plankton abundance along the North Adriatic neritic zone had been detected earlier (e.g. Franco 1973, Revelante \& Gilmartin 1976). In the Adriatic (Stn 36), the microzooplankton biomass was also high: $83 \mathrm{mg}$ $\mathrm{m}^{-3}$ in the upper water layer and about $1 \mathrm{~g} \mathrm{~m}^{-2}$ in the water column. So, its high level in the lagoon of Venice is also supported by populations carried into it by tidal water from the Adriatic. The importance of microzooplankton in the pelagic communities of the northern Adriatic has also been mentioned in other studies (Sorokin 1975a, b, Rassoulzadegan 1977, Revelante \& Gilmartin 1983, 1990, Cabrini et al. 1989).

The composition of microzooplankton reflects pollution effects, especially in the central lagoon, where the organisms most sensitive to industrial pollution, like rotifers and nauplii, were extremely rare, whereas they accounted for a significant portion of the microzooplankton in the cleaner southern areas. Tintinnids, which have long been recognized as important representatives of Adriatic ciliate populations (Krsinic 1982), appeared to be very rare, both in the lagoon and in the sea. The ciliate biomass was almost entirely $(95$ to $99 \%$ ) composed of aloricated oligotrichids. The role of microzooplankton in the energy flow was secondary to that of bacterioplankton (Table 7). Its production and respiration rates in cleaner areas like the Adriatic and the Chioggia and Lido areas were 1.2 to 2 times greater than those of mesozooplankton, while in highly polluted areas they were more than 50 times greater. In such areas, microzooplankton has the function of main grazer and decomposer of accumulating bacterial biomass (Figs. 8 \& 9). Its inhibition or depletion by industrial pollution may result in degradation of the environment. This often neglected component of plankton therefore deserves special attention during ecological monitoring of the lagoon. The ratios of microzooplankton and mesozooplankton by biomass and metabolic activity (energy flow respiration, production) may be used as indicators of the 'health' of a lagoonal ecosystem. 
The distribution, density and composition of mesozooplankton varied in different areas of the lagoon according to factors like pollution level, water turbidity, water exchange with the sea, and the presence of Tapes philippinarum and suspended mussel Mytilus galloprovincialis farming fields. In areas of industrial pollution or in oil-polluted port areas, mesozooplankton was either represented by a few deformed, injured Adriatic copepods or was absent. In areas of high water exchange near the port entrances, the lagoonal waters contained the Adriatic calanid cyclopid SagittaPenilia complex of mesozooplankton. In the North Adriatic, the mean biomass of this complex usually ranges from 100 to $250 \mathrm{mg} \mathrm{m}^{-3}$ (wet weight) or 15 to $40 \mathrm{mg}$ (dry weight; Comaschi 1972, Ferrari et al. 1982, Franco 1983, Benovic et al. 1984, Ghirardelli 1984, Cattani \& Corni 1992). Near the clam and mussel fields, a significant proportion of zooplankton is composed of larvae and juveniles of fauna inhabiting the aquaculture structures, such as zoea, young shrimp, stomatopods and harpacticoids. At most stations in the central basin of the lagoon and in the Palude della Rosa, the mesozooplankton was clearly inhibited both by pollution and by high water turbidity. Turbidity decreases the filtering efficiency of calanids and especially of Penilia, and also decreases the hunting efficiency of Sagitta, so that these groups are the first to disappear in turbid or polluted waters (Recve 1966, Pavlova 1967).

In the southern lagoon, the sea and the Venice-Lido area with high water exchange, where the waters contain abundant mesozooplankton, most or all of the microbial biomass produced is grazed. This fact reveals the normal functioning of the pelagic food web in parts of the lagoon not damaged by pollution or enhanced turbidity (Figs. 4, 5 \& 7). A relatively high quota of living biomass in suspended organic matter (Table 5) is important for the normal functioning of filter feeding grazers. In the Adriatic, this quota was $30 \%$, while in the central basin it was only 9 to $11 \%$, and at some stations $(19,21,23)$ only 3 to $5 \%$.

Summarized data on production-decomposition rates and their ratios are given in Tables $5 \& 7$. They demonstrate that the decomposition process of heterotrophic respiration in the water column in the central basin completely predominated over pelagic primary production. In many cases, the decomposition rate, estimated as total plankton respiration, was 10 to 100 times greater than pelagic primary production (average, 17 to 25 times for the central basin; Table 5: TM/PP ratio). This means that the main function of the pelagic ecosystem in this area is the self-purification of water from its excess of allochthonous organic matter, which arrives from both land and anthropogenic sources. Organic matter decomposition in this basin proceeds mainly due to the functioning of microbial components of the food web. The bacterial biomass resulting from bacterioplankton production is quite efficiently grazed and decomposed by protozoans (Table 7, Figs. 7-9). But this process results in the accumulation of their own biomass, which is poorly grazed by the depleted mesozooplankton, as may be seen in the energy flows (Figs. 8 \& 9). Available data from the literature on zoobenthos are not really quantitative for proper evaluation of their role in the degradation of the microbial biomass (Cairo et al. 1993). Analysis of energy flows and energy balances in pelagic communities of the lagoon of Venice proves that, at present, self-purification processes proceed with significant efficiency even in its polluted areas. The estimated time of complete water self-purification indicated by the LOM/TM ratio ranged between 10 and $20 \mathrm{~d}$ (Table 5), and was as low as 6 to $8 \mathrm{~d}$ at some stations $(2,7,20,26,30,34)$. Therefore, even in the stressed areas, where mesozooplankton (and most probably also zoobenthos) are depleted, the microbial food web still works efficiently in decomposing the bacterial biomass. The LOM stock usually comprises a small part of the total organic matter contained in sea water. In coastal waters it accounts for 15 to $25 \%$ and as absolute contents 0.6 to $1.2 \mathrm{mg} \mathrm{C} \mathrm{l}^{-1}$ (Zsolnay 1975 , Sorokin et al. 1983, Tchebotarev \& Sorokin 1983). At Stn 36 in the Adriatic, it was $1.07 \mathrm{mg} \mathrm{Cl}^{-1}$. In the lagoon, it was highest in the central basin (average contents, 2.5 to $2.8 \mathrm{mg} \mathrm{C} \mathrm{l}^{-1}$; Table 5). This means that the balance of LOM decomposition and the build-up of its stock from various sources is shifted towards accumulation in water, in spite of significant removal with tidal currents. The water arriving in the lagoon with incoming tides contains about $1 \mathrm{mg} \mathrm{Cl}^{-1}$ of LOM. When it leaves the lagoon, it may contain more than $2 \mathrm{mg} \mathrm{Cl}^{-1}$. This flux of excess LOM from the lagoon of Venice will inevitably accelerate the eutrophication of neritic waters along NW Adriatic coasts, so that this factor too must be carefully quantified and monitored.

The lagoonal waters also contain a high load of sus-

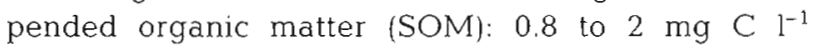
(Table 5). The living organic matter of plankton roughly comprises only 10 to $20 \%$; the rest is the dead organic matter of detritus (Faganelli \& Malej 1981). As it is not directly digestible by filtering fauna, it settles on the bottom and stimulates the formation of black mud or blackish silty sand by enhancing microbial sulfate reduction. The build-up of inert organic detritus, which exceeds by a factor of 2 to 3 its normal presence in clean neritic waters, is one of the most dangerous consequences of the continuing anthropogenic transformation of the lagoon of Venice (Carbognin \& Gatto 1981, Cossu et al. 1984). It inhibits the activity of pelagic and benthic filterers and thus reduces the selfpurification potential of the lagoonal ecosystem. 
The accumulation of labile sulfides in the upper layer of shallow bottom sediments directly in contact with oxygenated waters is possible if the flow of organic matter from the water column to the sediments is sufficient to support the rate of microbial sulfate reduction which exceeds the rate of sulfide oxidation. The contents of labile sulfides in the sediments of the central basin 2 to 5 m deep had been recorded in 1972 as 140 to $300 \mathrm{mg} \mathrm{dm}^{-3}$ of wet silt (Sorokin 1975a). Now their range is 800 to $2300 \mathrm{mg} \mathrm{S} \mathrm{dm}^{-3}$ (Table 4), and their levels are especially high in the black mud forming in areas directly affected by the Venice and Marghera effluent. The latter value actually corresponds to the highest ever recorded in marine sediments, even in well-known sulfur marine basins. For example, the contents of labile sulfides in sediments from the anoxic zone of the Black Sea does not exceed 1300 to $1400 \mathrm{mg}$ $\mathrm{S} \mathrm{dm}^{-3}$ (Sorokin 1982b). The level of 1500 to 2000 has only been recorded in anthropogenically stressed lagoonal basins and lakes (Sorokin \& Bilio 1981, Sorokin 1982a). The sediments often do not contain enough iron to bind such high loads of sulfides. They endanger the overlying water column by the possible evolution of free $\mathrm{H}_{2} \mathrm{~S}$ from the bottom. The latter is most possible during periods of temporary anoxia or accelerated sedimentation of organic matter, when aggressive $\mathrm{CO}_{2}$ forming as a result of its decomposition replaces free $\mathrm{H}_{2} \mathrm{~S}$ from labile forms such as $\mathrm{CaS}$ : CaS $+\mathrm{CO}_{2}+\mathrm{H}_{2} \mathrm{O} \rightarrow$ $\mathrm{CaCO}_{3}+\mathrm{H}_{2} \mathrm{~S}$. When ascending the water column and reaching the atmosphere as an aerosol, hydrogen sulfide has various negative effects on the environment, ranging from poisoning of the fauna, acceleration of anoxia (Powell et al. 1979, Stakhowitsch 1984, Stakhowitsch \& Avcin 1988), corrosion of buildings, and even discoloration of paintings in museums. Therefore, the process of sulfur dynamics in the lagoon of Venice should be of primary priority during ecological monitoring (Zarkanellas 1979, Stefanon \& Boldrin 1982).

This work represents a first attempt at a holistic approach to the problems of the lagoon of Venice and may be a basis for future research in order to fill in present gaps.

Acknowledgements. This research was supported by grants from ICRAM and CNR in Venice. The authors thank Drs F. Dallaporta, G. Ravagnan and L. Alberighi for promotion and help with this work

\section{LITERATURE CITED}

Alberotanza L, Zucchetta G (1988) Caratteristiche delle acque della Laguna di Venexia. CNR-ISDGM, CCID, Venice, p 60

Benovic A, Fonda Umani S, Malej A, Specchi M (1984) Net zooplankton biomass in the Adriatic Sea. Mar Biol 79:209-218 Bernhard M, Rampi L, Zattera A (1967) A phytoplankton com- ponent not considered by the Utermöhl method. Pubbl Staz Zool Napoli 35:170-214

Cabrin ML, Milani S, Fonda Umani S, Honsell G (1989) Relazionı trofiche tra fitoplancton e microzooplancton nel Golfo d. Trieste. Oebalia 15(NS):383-396

Cairo A, Brunetti R, Castello S, Tolomio C (1993) Indagini ch.mico-fisiche e biologiche sulla laguna di Venezia, 1991-1993. Dept Biologia, Università di Padova, p 115

Carbognin L, Gatto P (1981) The lagoon of Venice: natural environmental trend and man-induced modification. Hydrol Sci Bull 26:379-391

Caron DA (1983) Enumeration of heterotrophic nanoplankton using epifluorescence microscopy. Appl Environ Microbiol 46:491-498

Cattani O, Corni MG (1992) Role of zooplankton in eutrophication. In: Volleinveider R (ed) Marine coastal eutrophication. Elsevier, Amsterdam, p 137-147

Cescon B, Grancini G (1981) On some aspects of the marine population in Venice lagoon. Boll Geofis Teor Appl 8(49): $36-43$

Comaschi A (1972) Studio sulla biomassa zooplanctonica nella Laguna di Venezia. Atti Ist Veneto Sci Lett Arti 140: $117-146$

Corni MG, Giaccaglia G, Cattani O (1980) Zoocenosi superficiali al largo di Cesenatico. Nova Thalassia 4:63-73

Cossu R, Degobbis D, Donazzolo R (1984) II ruolo dei sedimenti nell'eutrofizzazione della laguna di Venezia. Ing Sanit $4: 10-12$

Dalla Venezia L (1996) Research activities in the Venice lagoon made by the CNR Institute of Marine Biology. Atti VI Congr S.IT.E. ATTI 16:87-89

Edmondson WI, Vinberg VV (1971) A manual for the assessment of secondary productivity in freshwaters. Blackwell, Oxford, p 358

Faganelli J, Malej A (1981) Carbon and nitrogen in suspended organic matter particulate and zooplankton. Rapp PV Réun. Comm Int Explor Scient Mer Méditerr 27:135-137

Ferrari I, Ceccherelli VU, Mazzocchi MG (1982) Seasonal and diel variations of zooplankton in a lagoon of Po river delta. Neth J Sea Res 16:333-344

Franco P (1973) Influenza del Po sui caratteri oceanografici e sulla biomassa planctonica dell'Adriatico Settentrionale. Ann Univ Ferrara Sez B 1:85-117

Franco P (1983) L'Adriatico Settentrionale: caratteri oceanografici e problemi. Atti V Congr AIOL. Venezia, p 1-27

Ghirardelli E (1984) Lo zooplancton degli ambienti neritici Nova Thalassia 6(Suppl):9-29

Grese VN (1979) Fundamentals of biological productivity in the Black Sea. Naukova Dumka, Kiev, p 350 (in Russian)

Hobbie JE, Daley RJ, Jasper S (1977) Use of Nuclepore filters for counting bacteria by fluorescent microscopy. Appl Environ Microbiol 33:1225-1228

Krsinic F (1982) On vertical distnbution of tintinnids in open waters of Southern Adriatic. Mar Biol 68:83-90

Marchesoni $V$ (1954) Il trofismo della laguna veneta: variazioni del fitoplancton. Arch Oceanogr Limnol 9:153-285

Marchetti R, Gaggino GF, Provini A (1988) Red tides in the NW Adriatic. UNESCO Bull Már Sci 49:133-142

Pavelieva EB, Sorokin YuI (1972) Evaluation of zooplankton catchability with vanous tools. Inform Bull Inst Freshwat Biol 'BoROK' Acad Sci USSR 15:75-79 (in Russian)

Pavlova EV (1967) Food utilization and energy transformation by cladoceran populations in the Black Sea. Biology of the Sea, Kiev, 4:66-85 (in Russian)

Perin G, Gabelli A (1983) Inquinamento chimico della Laguna di Venezia. Contaminanti di origine urbana e industriale nelle acque. Acqua Aria 6:615-621 
Rassoulzadegan F (1977) Evolution annuelle des ciliés pélagiques en Méditerranée Nord-Occidentale. Ann Inst Océanogr, Paris 53:125-134

Recve MR (1966) Observations on the biology of chaetognaths. In: Burnes $\mathrm{H}$ (ed) Studies in marine science. Allen and Unwin, London, p 613-630

Revelante N, Gilmartin $M$ (1976) The effect of Po river on phytoplankton dynamics in the North Adriatıc. Mar Biol $34: 259-271$

Revelante N, Gilmartin M (1983) Microzooplankton in the Northern Adriatic sea. Oceanol Acta 6:407-415

Revelante $N$, Gilmartin M (1990) Vertical water column resource partitioning by a ciliated protozoa in Adriatic J Plankton Res 12:89-107

Sherr B, Sherr E (1983) Enumeration of heterotrophic microprotozod by epifluorescence microscopy. Estuar Coast Shelf Sci 16:1-7

Socal G (1979) Nota sulla distribuzione quantitativa del fitoplancton nel bacino settentrionale della Laguna di Venezia. Rapp Studi 8:105-119

Socal G, Boldrin A, Bianchi F (1985) Ciclo annuale e diversità del fitoplancton nel porto Malamocco, Laguna di Venezia. Atti Ist Veneto Sci Lett Arti 143:15-30

Sorokin YuI (1960) Vertical distribution of phytoplankton and the primary production in the sea. J Cons Int Explor Mer 24:49-56

Sorokin Yul (1972) Biological productivity of the Rybinsk reservoir. In: Kajak $Z$, Hillbricht $A$ (eds) Productivity problems of freshwater. Pol Acad Sci, Warszawa-Krakov, p 493-503

Sorokın Yul (1975a) Sulfide formation and chemical composition of bottom sediments of some Italian lakes. Hydrobiologia 47:231-240

Sorokin Yul (1975b) Seasonal changes in microplankton of the Venetian lagoon. J Gen Biology (Moscow) 36:716-724 (in Russian)

Sorokin Yul (1980) Chamber for living counts of planktonic protozoa. Hydrobiol J (Kiev) 16(6):84-86 (in Russian)

Sorokin Yul (1981) Microheterotrophic organisms in marine ecosystems. In: Longhurst $L$ (ed) Analysis of marine ecosystems. Academic Press, New York, p 233-342

Sorokin YuI (1982a) Bacterial sulfate reduction in bottom sediments in some water basins of Italy. Hydrobiol J (Kiev) 18(4):38-44 (in Russian)

Sorokin Yul (1982b) The Black Sea. Nauka, Moscow, p 216 (in Russian)

Sorokin YuI (1985) Phosphorus metabolism in planktonic communities of the eastern tropical Pacific Ocean. Mar Ecol Prog Ser 27:87-97

Sorokin Yul (1987) On the adequacy of ${ }^{14} \mathrm{C}$ method in measurements of primary production. Oceanology (Moscow) $27: 676-682$

This article was submitted to the editor
Sorokin YuI (1990) Comparatıve evaluation of isotopic methods for measuring microbial production in the sea. Arch Hydrobiol Beih Ergeb Limnol 34:157-164

Sorokin Yul (1993) Report on ecological recearch in the Ca' Pisani lagoons. C.E.A.C., Contarina

Sorokin YuI, Bilio M (1981) Studies of microbial sulfate reduction and microplankton in the fish culture ponds of Comacchio region. Biology of the Sea (Vladivostok) 2: $50-58$ (in Russian)

Sorokin YuI, Mamaeva TI (1980) Rate and efficiency of utilization of labile organic matter by planktonic microflora in Peruvian waters. Pol Arch Hydrobiol 27:447-456

Sorokin Yul, Sorokin PYu, Gnes A (1993) Report on ecological research in the Comacchio lagoons. SIVALCO, Comacchio

Sorokin YuI, Tyapkin VS, Nhuen TA (1983) Energy inteconnection between bottom biocoenoses of coral reefs and adjacent oceanic waters. Biology of the Sea (Vladivostok) 3:29-38 (in Russian)

Stakhowitsch M (1984) Mass mortality in the Gulf of Trieste. Mar Ecol 5:243-264

Stakhowitsch M, Avcin A (1988) Eutrophication induced modification of benthic communities. UNESCO Rep Mar Sci 49:67-80

Stefanon A, Boldrin A (1982) The oxygen crisis in the Northern Adriatic and its effects on benthic communities. Proc 6th Symp CMAS, p 167-175

Sukhanova IN, Ratkova TN (1977) Comparison of sedimentation and double filtration methodology of phytoplankton. Okeanologiya (Moscow) 17:692-698 (in Russian)

Tchebotarev YuS, Sorokin YuI (1983) Stock of labile organic matter and its rate of decomposition in coastal waters. In: Sorokin Yul (ed) Seasonal changes in the Black Sea plankton. Nauka, Moscow, p 123-128 (in Russian)

Tchislenko LL (1968) The monograms for estimation of weight of aquatic organisms after their size. Nauka, Leningrad, p 105 (in Russian)

UNESCO (1988) UNESCO Rep Mar Sci 49

Vinogradov ME, Shushkina EA (1987) Functioning of the epipelagic planktonic communities. Nauka, Moscow, p 240 (in Russian)

Voltolina D (1973) A phytoplankton bloom in the lagoon of Venice. Arch Oceanogr Limnol 18:1-37

Zaika VE (1973) Specific production of aquatic invertebrates. Wiley, London, p 230

Zarkanellas AI (1979) The effects of population induced oxygen deficiency on the benthos in the Elefsis Bay, Greece. Mar Environ Res 2:191-207

Zsolnay J (1975) Total labile carbon in the Baltic Sea as measured by BOD. Mar Biol 29:125-128

Zucchetta G (1983) L'inquinarnento della Laguna di Venezia. Ateneo Veneto 21 (N2) II sem

Manuscript first received: October 2, 1995

Revised version accepted: April 29, 1996 